Revised August 23, 2015

BSP Special Issue of Deep-Sea Research II

\title{
Mesozooplankton grazing during spring sea-ice conditions in the eastern Bering Sea
}

${ }^{a}$ Graduate School of Oceanography, University of Rhode Island, Narragansett, RI 02882, USA

${ }^{b}$ Woods Hole Oceanographic Institution, Woods Hole, MA 02543, USA

${ }^{\mathrm{c}}$ College of Oceanic and Atmospheric Sciences, Oregon State University, Corvallis, OR 97331, USA

${ }^{\mathrm{d}}$ Bigelow Laboratory for Ocean Sciences, East Boothbay, ME 04544, USA

*Corresponding author: Tel: 401-874-6692

E-mail address: campbell@gso.uri.edu

\author{
Robert G. Campbell ${ }^{\mathrm{a} *}$ \\ Carin J. Ashjian ${ }^{\mathrm{b}}$ \\ Evelyn B. Sherr ${ }^{\mathrm{c}}$ \\ Barry F. Sherr ${ }^{\mathrm{C}}$ \\ Michael W Lomas ${ }^{\mathrm{d}}$ \\ Celia Ross ${ }^{\mathrm{c}}$ \\ Philip Alatalo ${ }^{\mathrm{b}}$ \\ Celia Gelfman ${ }^{\mathrm{a}}$ \\ Donna Van Keuren ${ }^{\mathrm{a}}$
}




\section{Abstract}

37 Mesozooplankton (copepods and euphausiids) grazing rates and prey preferences were

38 determined during a series of three research cruises to the eastern Bering Sea in spring 2008,

392009 , and 2010. Chlorophyll was dominated by large cells ( $>5 \mu \mathrm{m})$, especially at bloom

40 locations where they usually comprised greater than $90 \%$ of the total chlorophyll biomass. The

41 relative importance of microzooplankton to the prey field biomass decreased with increasing

42 chlorophyll concentration, and was less than $10 \%$ of the total prey biomass in ice-edge bloom

43 regions. Overall, microzooplankton was the preferred prey of the mesozooplankton, although

44 phytoplankton/ice algae were the dominant component of the diet because of their much greater

45 biomass, especially during blooms. There were differences between mesozooplankton species in

46 their prey preferences: Metridia pacifica, Pseudocalanus spp. and Calanus spp. had the strongest

47 preference for microzooplankton prey, while euphausiids (Thysanoessa spp.) and Neocalanus

48 flemingeri/plumchrus appeared to feed non-selectively on all prey items. Mesozooplankton

49 exhibited a saturating feeding response to chlorophyll concentration (Holling's type II) that could

50 be modeled by Michaelis-Menten equations. Taxa-specific maximum ingestion rates generally

51 followed allometric theory, with smaller zooplankton having higher feeding rates than larger

52 zooplankton, and ranged from about $4 \%$ to $30 \%$ body carbon day ${ }^{-1}$. Trophic cascades during

53 grazing experiments could result in a substantial underestimate of chlorophyll ingestion rates,

54 especially for those taxa that had a strong preference for microzooplankton. Grazing impacts by

55 mesozooplankton on the integrated chlorophyll biomass and primary production were $2.7 \pm 4.4$

56 and $26 \pm 48 \%$ day $^{-1}$, respectively. Impacts increased significantly with increasing

57 mesozooplankton biomass, which increased from early to late spring. However, grazing impacts 
58 were extremely low in ice-edge bloom regions. Our findings suggest that even when grazing by

59 microzooplankton is included in our grazing impact estimates, about $50 \%$ of the primary

60 production in phytoplankton blooms during spring on the eastern Bering Sea shelf is not grazed

61 and is available for direct export to the benthic community.

62

63 Keywords: Copepod, Euphausiid, Ingestion, Diets, Prey Selection, Grazing Impact, Spring

64 Bloom 


\section{Introduction:}

67 The eastern Bering Sea supports one of the richest fisheries in the world's oceans and provides

68 almost half of the total U.S. fish catch annually (e.g. Sigler et al., 2010). This rich fishery can in

69 part be attributed to the highly productive ice algal and phytoplankton spring blooms that occur

70 as the sea ice retreats. These blooms, in turn, support a highly diverse planktonic food web of

71 micro- and mesozooplankton grazers, many of which time their reproductive cycles to the spring

72 bloom (e.g. Baier and Napp, 2003). The mesozooplankton, in particular, provide a rich prey

73 supply for an array of upper trophic level predators, including fish (especially larval pollock),

74 seabirds, and marine mammals (e.g., Bailey and Dunn, 1979; Brodeur et al., 2002; Cianelli et al.,

75 2004; Dwyer et al., 1987; Moore et al., 2002; Springer et al., 1989; Springer and Roseaneau,

76 1985; Stabeno et al., 2012a, 2012b; Tynan, 2004; Tynan et al., 2001). The timing of these

77 blooms also is important to life cycles of higher trophic levels since it can determine the

78 productivity and energy pathways of the ecosystem. Hunt et al. (2002) hypothesized in their

79 Oscillating Control Hypothesis $(\mathrm{OCH})$, that during warm periods, the ice retreats earlier and the

80 bloom occurs later in open, thermally stratified waters at warmer temperatures, while during cold

81 periods, the ice retreats later and the bloom occurs earlier in association with the retreating ice

82 edge and salinity stratified, colder water. During warm periods, much of the spring production is

83 retained in the water column through higher, temperature-mediated grazing and production by

84 zooplankton that then supports pelagic fish. In contrast, during cold periods temperature limits

85 grazing and much of the production falls to the bottom, supporting the benthic communities.

86 However, recent studies have suggested a slightly more complicated scenario in that some larger

87 mesozooplankton (e.g. Calanus) are more productive during cold years, less so in warm years, 
88 with consequences during warm years for their fish predators that depend on them (Coyle et al.,

89 2011; Heintz et al., 2013; Hunt et al., 2011; Sigler et al., 2014).

91 The southeastern Bering Sea shelf is differentiated into three, bathymetrically-fixed

92 hydrographic regions; the Coastal or Inner Domain (shore- 50 m water depth), the Middle Shelf

93 Domain (50-100 m), and the Outer Shelf Domain (100-200 m) (Coachman, 1986; Iverson et al.,

94 1979; Schumacher and Stabeno, 1998; Stabeno et al., 2001). Each of the three hydrographic

95 domains contains characteristic mesozooplankton species (e.g., Cooney and Coyle 1982; Coyle

96 and Pinchuk, 2002; Dagg et al., 1982; Smith and Vidal 1984, 1986; Springer et al., 1989; Smith

97 1991; Stockwell et al., 2001; Vidal and Smith 1986). Although, it is not clear if the domains

98 maintain their integrity in the middle and northern Bering Sea, these same species are present

99 there (e.g., Springer et al., 1989; Eisner et al., 2014). The outer domain is characterized by the

100 oceanic copepod species Neocalanus plumchrus, N. flemingeri, N. cristatus, Eucalanus bungii,

101 and Metridia pacifica, and the euphausiid Thysanoessa inermis. The middle shelf is dominated

102 by Calanus glacialis/marshallae (two co-occurring species that are difficult to tell apart) and the

103 euphausiid T. raschii, with the much smaller copepod species Acartia longiremis and

104 Pseudocalanus spp. abundant, but not important to biomass at least during spring. The small

105 copepod Oithona similis is present in both domains and is numerically dominant. The inner

106 domain contains smaller, neritic copepods (e.g., A. longiremis, Pseudocalanus spp., Eurytemora

107 spp.) and the euphausiid $T$. raschii. The two euphausiid species are relatively small with only

108 the adults large enough, but just barely so, to be classified as macrozooplankton $(20-200 \mathrm{~mm})$.

109 It has been shown that in recent years there are differences in community composition, in terms 
110 of relative abundance, between the north and south regions and warm and cold regimes,

111 especially in the middle domain (Eisner et al., 2014).

112

113 Most mesozooplankton previously believed to be herbivorous are now considered to be

114 omnivorous, utilizing phytoplankton, ice algae, and microzooplankton depending on relative

115 availability with preference changing seasonally as the dominant food supply changes (Campbell

116 et al., 2009; Conover et al., 1986; Dagg 1993; Gifford 1993; Kleppel 1993; Landry1993; Ohman

117 and Runge 1994; Rivkin et al., 1996; Runge and Ingram 1988; Runge et al., 1991; Tourangeau

118 and Runge 1991). To understand the potential impact of a reduced ice cover on the cycling of

119 carbon in these ecosystems, it is critical to gain an understanding of the relative importance of

120 ice algae, phytoplankton, and microzooplankton to the diet of the key mesozooplankton species,

121 the grazing impact of these species on prey standing stocks, and how these preferences and

122 impacts change under various conditions of ice cover and water column stability.

123

124 We present results from mesozooplankton grazing experiments conducted in the eastern Bering

125 Sea in spring sea-ice conditions during three "cold years" as part of the Bering Sea Program.

126 These studies were conducted in parallel with dilution assays to estimate microzooplankton

127 grazing (Sherr et al. 2013) to gain a better understanding of the planktonic food web during

128 spring. This study was guided by two overarching hypotheses: (1) Mesozooplankton are

129 omnivorous; the importance of microzooplankton in the diet will depend on the prey preferences

130 of individual mesozooplankton species and will be influenced by their relative abundance in the

131 prey field. (2) Mesozooplankton grazing impacts will depend on total grazer biomass and

132 phytoplankton biomass/productivity, which will vary across the shelf domains, latitudinal 
133 regions, years, and bloom conditions. Here we describe the prey preferences, ingestion rates,

134 and the grazing impacts on primary production and chlorophyll standing stock for the dominant

135 mesozooplankton taxa.

136

\section{2. Methods}

139 Shipboard grazing experiments were conducted in spring (April-June) on the eastern Bering Sea

140 shelf in 2008, 2009, and 2010 (Figure 1). The methods closely followed those outlined in

141 Campbell et al., (2009). Mesozooplankton grazing experiments were conducted usually every

142 other day at stations where a comprehensive suite of ecological measurements was performed,

143 including determination of primary production and microzooplankton grazing (Lomas et al.,

144 2012; Sherr et al., 2013). The mesozooplankton species/life stages that were dominant in terms

145 of biomass at each location were selected for inclusion in the experiments. These included the

146 copepods Calanus glacialis/marshallae, Pseudocalanus spp., Metridia pacifica, Neocalanus

147 flemingeri/plumchrus (referred to here as Neocalanus spp.), N. cristatus, and Eucalanus bungii,

148 among others, and euphausiids, primarily Thysanoessa raschii and T. inermis.

150 2.1. Experiments

151 Feeding rates were measured using natural particle assemblages or natural assemblages enriched

152 with ice algae in on-deck incubations in a plankton wheel/water bath under ambient light and

153 temperature conditions. Animals for experiments were collected in the pre-dawn hours with

154 gentle, vertical hauls of a $1-\mathrm{m}^{2}, 200-\mu \mathrm{m}$ mesh plankton net equipped with a 4-1, non-filtering cod

155 end. Upon reaching the surface, animals were immediately diluted into jars containing surface 
156 water, placed in coolers and transported to an environmental chamber that was maintained at

157 near the ambient surface seawater temperature (usually $\sim-1.8^{\circ} \mathrm{C}$ due to the presence of sea ice).

158 All sorting of animals and handling of water was done in the environmental chamber.

160 Water for the experiments was collected in 30-1 Niskin bottles equipped with Viton o-rings and

161 nylon coated steel springs, and attached to a CTD rosette with a fluorometer and

162 photosynthetically available radiation (PAR) sensor. An initial cast was made to determine the

163 water column profile from which the water collection depth was selected. Water was generally

164 collected from the surface chlorophyll maximum. On occasion, when a deep chlorophyll

165 maximum layer was present, water was collected from both the deep layer and the surface mixed

166 layer. Upon retrieval, water was drained from the Niskin bottles into 50-1 high-density

167 polyethylene carboys (HDPE) using silicone tubing and immediately transferred to the

168 environmental chamber. All water handling equipment was pre-cleaned in 10\% HCL and rinsed

169 with copious amounts of de-ionized water prior to use, and all procedures were performed using

170 nitrile gloves. The initial nutrient concentrations were determined in the experimental water

171 prior to the start of the experiments by the hydrography team. Nutrients (ammonium nitrate and

172 sodium phosphate) were added as needed to the experimental water to bring concentrations to 5

$173 \mu \mathrm{M} \mathrm{N}$ and $0.25 \mu \mathrm{M}$ P to ensure that phytoplankton growth rates were not limited and were

174 equivalent in control and experimental bottles. Experimental water was then siphoned using

175 silicone tubing, while being gently mixed with a long-handled PVC plunger into experimental

176 bottles (1- to 4-L polycarbonate bottles) in random order. The bottles were visually inspected

177 and any large zooplankton that had been unintentionally added were removed by pipette. 
179 At selected locations, a treatment enriched with an ice algal community was included in addition

180 to the ambient treatment. Chunks of ice containing ice algae were obtained from ice cores

181 provided by R. Gradinger or collected with long-handled dip nets from the stern of the ship. The

182 ice was allowed to melt in filtered seawater, overnight, in the dark, while being maintained at

183 near ambient temperature in the environmental chamber. The ice algal community was then

184 added to a separate carboy collected from the same depth as the ambient treatment enriching the

185 chlorophyll concentration by 5 to $10 \mu \mathrm{g}^{-1}$. Handling of the enriched water was the same as for

186 the ambient water treatment.

187

188 Animals for the experiments were generally sorted within an hour of collection. For copepods,

189 sorting was performed with a large bore pipette and the aid of a dissecting microscope. Animals

190 were sorted to genus/species and life stage. A double sort was employed to insure both proper

191 identification and that the animals were active and in good condition. Euphausiids were sorted by

192 eye from a dishpan with small plastic spoons. Again, great care was taken to make sure that they

193 were in good condition. All experimental animals were kept in filtered seawater until the start of

194 the experiment, generally about an hour.

196 For each treatment, three initial and three control treatments in 1- or 2-L bottles and three

197 experimental bottles per target animal type, with the bottle size (1- to 4-L) dependent on the size

198 of the animal type, were prepared by nearly filling each bottle with experimental seawater. A

199 predetermined number of animals was added to each experimental bottle in a minimum amount

200 of water so that the experimental particle concentration was unaltered. The number of animals

201 was chosen so that $\sim 25-30 \%$ of the water would be cleared by the animals during the $24-\mathrm{hr}$ 
202 incubation period based on similar grazing studies in Chukchi Sea (Campbell et al., 2009). For

203 example, depending on chlorophyll concentration, 20-40 adult female Pseudocalanus, 5-10 adult

204 female Calanus, and 2-4 large juvenile/adult euphausiids were added to 1, 2, and 4-L bottles,

205 respectively. All bottles were then topped off with make-up experimental water, sealed with

206 parafilm to ensure that no bubbles were present that might alter the feeding behavior, and capped.

207 The control and experimental bottles were then wrapped in colored plastic films to mimic the

208 light quality and intensity from depth that the water was collected. They were incubated on-deck

209 in a transparent polycarbonate 1-rpm plankton wheel enclosed in a water bath that was exposed

210 to natural light conditions and kept at ambient temperature with continuous flowing surface

211 seawater. Water bath temperatures during the experiments were monitored using submersed

212 HOBO temperature recorders (Onset Computers Inc.).

214 Chlorophyll (total and $<5 \mu \mathrm{m}$ ) and microzooplankton samples were collected at the start of the

215 experiment from the initial bottles and at the termination from the control and experimental

216 bottles. Sampling from all bottles followed the same protocol. The bottles were gently inverted

217 by hand to mix the water. The water was then siphoned from the bottles into a beaker taking

218 care not to remove animals from the experimental bottles. If per chance animals were siphoned

219 from the bottles they were removed from the beaker by pipette and saved. The required volume

220 of water was then measured using a graduated cylinder and saved for each analysis. For

221 chlorophyll analysis, the $<5 \mu \mathrm{m}$ fraction was created by gently sieving water through $5-\mu \mathrm{m}$ mesh.

222 The sample for the total size fraction was left unaltered. Triplicate samples of 50-500 ml,

223 depending on estimates of chlorophyll concentration, were filtered onto Whatman GF/F filters

224 and immediately extracted in $90 \%$ acetone at $-20{ }^{\circ} \mathrm{C}$ for $18-24 \mathrm{hr}$. The chlorophyll $a$ 
225 concentration was determined with a Turner Designs fluorometer using the non-acidification

226 method of Welschmeyer (1994). The non-acidification method was deemed justified for

227 chlorophyll determination during the spring-bloom period, as degraded pigments should be at a

228 minimum. To convert chlorophyll to carbon/nitrogen weight a POC or PON: Chl $a$ ratio of 50 for

229 carbon and 6.5 for nitrogen were used, which were determined from POC/N: Chl a relationships

230 for these cruises (Lomas et al., 2012; M. Lomas unpublished.). Samples (125 ml) were also

231 collected from each bottle for microzooplankton abundance and biomass and preserved in 5\%

232 acid-Lugol's solution in amber safety-coated glass bottles until analyzed by inverted microscopy

233 (See Sherr et al., 2013 for complete details of counting and sizing methodology). In brief,

234 between 15 and $50 \mathrm{ml}$ of the sample was settled for $24 \mathrm{hr}$, and then counted and measured with a

235 Nikon inverted microscope attached to computer digitizing system. From 60 to 400 cells were

236 counted and sized in each sample. Cell measurements were converted to cell volume with

237 appropriate equations, and the volume estimate converted to cell carbon. For dinoflagellates, cell

238 carbon content was estimated from the equations of Menden-Deuer and Lessard (2000), and for

239 ciliates, carbon was estimated using a value of $0.19 \mathrm{pg} \mathrm{C} \mu \mathrm{m}^{-3}$ (Putt and Stoecker, 1989).

241 Following the water sampling, animals were collected from the experimental bottles and

242 anesthetized with a solution of $0.6 \mathrm{~g} \mathrm{l}^{-1}$ of MS222 (3-aminobenzoic acid ethyl ester

243 methanesulfonate salt) in filtered seawater. Under a dissecting microscope, each animal was

244 identified, its relative condition determined, and an image taken with a high-resolution digital

245 camera for later morphometric analysis. The animal then was transferred to a tin boat, dried at

$24660^{\circ} \mathrm{C}$, and stored over desiccant until analyzed for carbon and nitrogen content with a Carlo 
247 Erba NA1500 elemental analyzer. Smaller animals (e.g. Pseudocalanus and Acartia) were

248 grouped for carbon and nitrogen analysis.

250 2.2. Prey Preferences

252 For the analysis of prey preferences, we compared 1) the proportion of the prey types in the diet

253 with those in the prey field and, 2) the clearance rates of different prey types. For the diet versus

254 prey type comparisons all negative ingestion estimates were converted to 0 . This did not likely

255 bias the data set as both the chlorophyll and microzooplankton ingestion measurements had the

256 same proportion of negative, mostly near 0 , values (11.3\%), and also the clearance rate

257 comparisons gave very similar results. No corrections were made to the clearance rate

258 comparisons. The electivity index D (Jacobs, 1974) was used to compare the preferences of

259 different taxa:

260

$261 D_{i}=\left(r_{i}-p_{i}\right) /\left(r_{i}+p_{i}-2 r_{i} p_{i}\right)$

263 where $D_{i}$ is the electivity index for prey type $i, r_{i}$ is the proportion of prey type $i$ in the prey field,

264 and $p_{i}$ is the proportion in the diet. The index values can range from -1 to 1,0 indicates no

265 selection and $D_{i}>0$ and $D_{i}<0$ indicate positive and negative selection, respectively. Because the

266 data were usually not normally distributed and in many cases variances were unequal, all

267 ANOVA and comparative statistical tests were non-parametric. All statistical analyses were

268 performed with the Prism 5 statistical software package (GraphPad Software, Inc.). 


\section{2.3. Grazing Rates}

272

273 Zooplankton clearance and ingestion rates were determined from the equations of Frost (1972)

274 for each of the different chlorophyll size fractions and microzooplankton types (ciliates and

275 dinoflagellates) and sizes on an individual and weight-specific basis (carbon and nitrogen for

276 chlorophyll, carbon only for microzooplankton). The relationships between food concentration

277 and ingestion followed a Holling's type 2 response, and so to describe the relationships

278 Michaelis-Menten functions were fit to the data with curve fitting routines in the DeltaGraph 5

279 software program (Redrock Software):

280

$281 \quad I=\left(V_{\max } * C\right) /\left(K_{m}+C\right)$

282

283 where $I$ is ingestion rate (individual or weight-specific), $V_{\max }$ is the maximum ingestion rate, $K_{m}$

284 is the food concentration at which the ingestion rate is half of $V_{\max }$, and $C$ is food concentration

285 in terms of chlorophyll $a$, nitrogen or carbon.

287 Relationships were fit to the uncorrected ingestion data, and to data corrected for the 288 experimental temperature and adjusted to $0{ }^{\circ} \mathrm{C}$ assuming a $\mathrm{Q}_{10}$ coefficient of 2.0. The

289 temperature correction was made to determine if temperature differences between experiments

290 had a significant effect on ingestion rate and the ingestion rate-chlorophyll relationships. It was

291 also used to correct for differences in field temperatures when estimating grazing impacts by

292 mesozooplankton at each station location. 
294 In addition, in a subset of experiments where ingestion rates were determined for both

295 chlorophyll $a$ and microzooplankton prey, and paired dilution assays were conducted to estimate

296 microzooplankton grazing rates, corrections were made to account for trophic cascades in the

297 grazing jars following the recommendations of Nejstgaard et al., (2001) and using their general

298 method. Because of the lack of mesozooplankton predation on microzooplankton in control jars,

299 microzooplankton grazing pressure in the control jars can be significantly higher than in the

300 experimental jars resulting in a lower apparent phytoplankton (chlorophyll) growth rate in the

301 control jars relative to the experimental jars and an underestimate of grazing by

302 mesozooplankton.

303

304 2.4. Grazing Impacts

305

306 Grazing impacts at each station were determined following Campbell et al. (2009) with several

307 modifications. All life stages of the top ten copepod taxa in terms of biomass including: Calanus

308 glacialis/marshallae, Pseudocalanus spp., Metridia pacifica, Acartia longiremis, Neocalanus

309 cristatus, N. flemingeri/plumchrus, Eucalanus bungii, Oithona similis, Microcalanus pygmaeus,

310 and Oncaea borealis, and all euphausiids were included in the estimates. Other taxa, including

311 meroplanktonic larvae and appendicularians were not included in the estimates because we

312 lacked ingestion rate measurements for them. However, this should not introduce a large error

313 into the estimate, as they were not very abundant compared to the copepods at our sampling

314 locations.

315 
316 Ingestion rates at each location were determined using the chlorophyll-dependent grazing rate

317 equations for each taxon and the maximum chlorophyll concentration at each location. For the

318 small copepod species (Acartia longiremis. Microcalanus pygmaeus, Oithona similis, and

319 Oncaea borealis) for which we did not have sufficient data to produce feeding relationships, we

320 used the relationship for Pseudocalanus spp. This should not inject a serious error into the

321 calculation as these species generally accounted for less than $10 \%$ of the total biomass. The rates

322 were adjusted for 1) body size (stage) for each taxa, assuming rates are proportional to body

323 weight (Wt. ${ }^{0.75}$; Kleiber 1947) and 2) mean field temperature (0-50 m) at each location assuming

$324 \mathrm{Q}_{10}=2.0$. Stage-specific body weights (carbon) were obtained from measurements of the carbon

325 content from field-collected specimens. For missing weights of younger stages, an estimate was

326 obtained from the ratio of the weight of the adult female to that of the missing stage from our

327 data or from the literature.

329 The integrated grazing rates were determined from the product of the individual species/stage

330 daily ingestion rates and their areal biomass estimates, and summed for all taxa. Zooplankton

331 areal biomass was estimated from vertically integrated bongo net tows $(150-\mu \mathrm{m})$ from $100-\mathrm{m}$, or

332 the bottom in shallower water, to the surface. Grazing impacts were expressed as the proportion

333 of the total integrated chlorophyll or the total integrated primary production (Lomas et al., 2012)

334 grazed at each station.

336 This method should provide an estimate of the maximum potential grazing impact of the

337 mesozooplankton population. By estimating the ingestion rate at the highest chlorophyll

338 concentration at the station we use the highest potential ingestion rate for that location. This 
339 method assumes that all mesozooplankton in the upper $100 \mathrm{~m}$ are actively feeding and growing,

340 they can move vertically to locate optimal feeding locations, and they don't need to remain in

341 these optimal layers and continually feed to obtain their daily ration. The alternative approach,

342 using clearance rates on the entire water column or just the mixed layer to estimate grazing

343 impacts, would generally provide a much lower estimate.

\section{3. Results}

347 A total of 50 grazing experiments were conducted in spring over the course of the three-year 348 study (2008-2010). There were 596 individual grazing estimates determined and samples from

349304 of those experiments were enumerated to estimate grazing on microzooplankton. Grazing

350 rates were determined for both the total and $>5 \mu \mathrm{m}$ chlorophyll $a$ size fractions at those locations

351 where the $<5 \mu \mathrm{m}$ size fraction exceeded about $5 \%$ of the total chlorophyll biomass. The

352 locations spanned the entire shelf and included inner $(<50 \mathrm{~m})$, middle $(50-100 \mathrm{~m})$ and outer

$353(>100 \mathrm{~m}$ ) domains, but were predominantly from the outer and middle shelf domains (Figure 1).

354

\section{3.1. Environmental Conditions}

357 All three years were considered "cold" years, but environmental conditions still varied

358 considerably between the cruises (Table 1). In 2008 and 2009, the research cruises were

359 conducted from the icebreaker USCGC Healy from early April to early May, while in 2010, the

360 cruise took place about a month later aboard the $R / V$ Thomas $G$. Thompson. Since the $R / V$

361 Thompson is not an icebreaker, experiments could not be conducted within the pack ice in 2010. 
362 In 2008 and 2009 the incubation temperatures (similar to ambient surface water temperature)

363 were about $3^{\circ} \mathrm{C}$ colder, on average, compared to the later cruise in 2010 . The mean chlorophyll

364 concentration and the microzooplankton biomass in the experimental water (taken from the

365 chlorophyll maximum) were greatest in the later spring cruise in 2010 compared to the earlier

366 spring cruises. The chlorophyll was dominated by larger cells, typical of a spring diatom bloom,

367 in all three years.

369 The prey-field composition showed a consistent pattern with respect to the stage of the spring

370 bloom (Figure 2). At bloom locations where chlorophyll concentrations exceeded about $2 \mu \mathrm{g} \mathrm{chl}$

$371 a 1^{-1}$, the proportion of the chlorophyll in the $>5 \mu \mathrm{m}$ size class generally was $90 \%$ or greater. At

372 pre-bloom locations, it was quite variable -ranging from $20-85 \%$. The phytoplankton

373 communities in the $>5-\mu \mathrm{m}$ size fraction were dominated by diatoms (Sherr et al. 2013), and were

374 comprised mainly of centric diatoms including Chaetoceros spp., Thalassiosira spp. and

375 Cylindrotheca spp. However, pennate diatoms, most likely of sea ice origin, Fragilariopsis spp.,

376 Navicula spp. and Nitzschia spp., could also be important in ice-covered regions. The proportion

377 of microzooplankton biomass of the total prey field was inversely related to the phytoplankton

378 biomass. In phytoplankton bloom conditions, the proportion of microzooplankton in the prey

379 field was mostly less than $10 \%$ of the total prey field biomass, while in pre-bloom conditions,

380 when chlorophyll was low and nutrient concentrations high, microzooplankton biomass could

381 approach $50 \%$ of the total prey field biomass. It is interesting to note that the ice biota enriched

382 treatments followed these same patterns: $>90 \%$ of the chlorophyll was in the $>5 \mu \mathrm{m}$ size-class,

383 dominated by pennate diatoms, and microzooplankton amounted to less than $10 \%$ of the total

384 prey field biomass. 


\subsection{Prey Preferences}

388 Mesozooplankton showed a strong preference for ice algal/phytoplankton cells larger than $5-\mu \mathrm{m}$ 389 (Figure 3, $\mathrm{p}<0.0001$, Wilcoxon Signed Ranks non-parametric test), as indicated by the higher 390 proportion of large cells in the diet compared to the prey field (points falling above the 1:1 line).

391 Similarly, mesozooplankton also preferred microzooplankton to chlorophyll (Figure 3; $\mathrm{p}<0.0001$,

392 Wilcoxon Signed Ranks non-parametric test). Even though there was a strong overall preference

393 for microzooplankton, the proportion of microzooplankton in the diet tended to decrease with

394 increasing chlorophyll ingestion rate, although there is a great amount of variability in the data at

395 low ingestion rates, indicating that it was a less important part of the diet when mesozooplankton

396 were feeding at high rates in bloom conditions (Figure 4). Examples are shown for Calanus

397 (adult females) and euphausiids (juveniles and adults) for which the most data are available.

398 Other taxa exhibited a similar response.

400 There were differences in the preference shown for microzooplankton as a food source between

401 taxa (Figure 5, Table 2). In particular, the copepods Calanus spp. and Pseudocalanus spp.

402 typical of the middle shelf and Metridia pacifica, typical of the outer shelf and slope, consumed 403 microzooplankton at about 2 to 7 times their relative proportions in the prey field. Other outer

404 shelf/slope copepods, including, Neocalanus spp. (N. flemingeri/plumchrus) and Eucalanus

405 bungii, and euphausiids (Thysanoessa spp.) fed readily on microzooplankton, but had much

406 weaker preferences for them. Calanus, Pseudocalanus, and Metridia, were not significantly

407 different from each other in their strong preference for microzooplankton prey, but they did have 
408 a significantly stronger preference than $N$. flemingeri/plumchrus, Eucalanus sp. and Thysanoessa

409 spp., which were not significantly different from each other. Neocalanus cristatus was not

410 significantly different from either group. Acartia was not included in the comparisons because of

411 small sample size $(\mathrm{n}=3)$, although microzooplankton were also preferentially ingested. The

412 Electivity Index and the pairwise comparisons between the proportion of microzooplankton in

413 the prey field and diet found the same patterns in preferences between the different taxa for the

414 most part (Table 2). Metridia, Pseudocalanus, and Calanus had the strongest preferences for

415 microzooplankton, while most copepods found in outer shelf/slope waters were much less

416 selective. Neocalanus flemingeri/plumchrus had no preference and Eucalanus bungii a weak, but

417 significant, preference for chlorophyll. Based on the prey field/diet comparisons, euphausiids

418 showed no preference, but did have a significant preference for chlorophyll based on the

419 electivity index. This result seems puzzling at first glance because the proportion of

420 microzooplankton in the diet is greater than the prey field. However, diet variability was much

421 higher than for other taxa and the statistical tests that were used were non-parametric, based on

422 ranks, not absolute values, and therefore not as powerful.

423

424 Preferences were found for different sizes and types of microzooplankton (Table 3). All

425 mesozooplankton had higher clearance rates, a measure of selectivity, on large $>40 \mu \mathrm{m}$ cells.

426 Only Pseudocalanus and Eucalanus did not have a significant preference for the larger cells. For

427 most species, there was no significant preference for ciliates vs. dinoflagellates, with the

428 exceptions of Metridia pacifica and euphausiids that both had a strong preference for ciliates.

429 The euphausiid preference was surprising since they did not show a preference in terms of

430 clearance rate for microzooplankton prey. 


\section{3.3. Ingestion Rates}

434 Maximum weight-specific ingestion of chlorophyll as a function of chlorophyll concentration, in 435 general, decreased with body size as would be predicted by allometric rules (Figure 6, Table 4),

436 although the relationship was not significant. For example: Pseudocalanus spp. females and 437 young Calanus spp. (C1-C4), the smallest taxa, had maximum ingestion rates of 20 to $30 \%$ body 438 carbon day $^{-1}$; Calanus spp. (adult/C5) and Neocalanus flemingeri/plumchrus (C4/C5), similar in

439 size, were on the order of $12 \%$ body carbon day ${ }^{-1} ;$ N. cristatus (C5), the largest copepod,

440 maximally fed at about $5 \%$ body carbon day $^{-1}$; and euphausiids, mainly Thysanoessa raschii and

441 T. inermis, had maximum ingestion rates of only $4 \%$ body carbon day ${ }^{-1}$. Metridia pacifica, a

442 small copepod with low maximum ingestion rates was an exception. It had the strongest

443 preference for microzooplankton and the poorest chlorophyll-ingestion rate relationships. Also, 444 young copepodids of Calanus had much higher maximum rates than would be expected given

445 their body weight. This might reflect higher relative food requirements of younger stages, as all

446 of the other measurements represent adults or older copepodid stages.

448 Michaelis-Menten relationships were determined for both total chlorophyll and the $>5 \mu \mathrm{m}$

449 chlorophyll size fraction in terms of \% body nitrogen and carbon for temperature-corrected and

450 uncorrected ingestion rates (Table 4). In almost all cases the relationships were better (higher

$451 \mathrm{R}^{2}$ ) for chlorophyll in the $>5 \mu \mathrm{m}$ size fraction than for total chlorophyll. Maximum nitrogen-

452 specific rates $\left(\mathrm{V}_{\max }\right)$ tended to be much lower than carbon-specific rates for most taxa. The rates

453 were more similar for taxa with high $\mathrm{C}: \mathrm{N}$ ratios that more closely approached those of the 
454 phytoplankton/ice algae communities, such as Neocalanus spp. and young stages of Calanus spp.

455 The half-saturation concentrations $\left(\mathrm{K}_{\mathrm{m}}\right)$, the chlorophyll concentration at which half of the

456 maximum ingestion rate is achieved, were generally similar for nitrogen and carbon based

457 ingestion rates. There were some large differences for some taxa, but no general pattern was

458 observed. Applying a temperature correction to bring all of the experimental rates to a constant

459 temperature of $0^{\circ} \mathrm{C}$ did not improve the fit $\left(\mathrm{R}^{2}\right)$ of the data to the model for most taxa.

460 Providing for larger temperature compensation by increasing the $\mathrm{Q}_{10}$ coefficient from 2 to 2.8

461 tended to further worsen the fit (not shown). However, temperature corrections did improve the

462 fit for Metridia pacifica and Neocalanus spp.

463

464 Calanus spp., Pseudocalanus spp. and euphausiids readily fed on ice algae when offered in

465 enriched treatments (Figure 7A, C, H). Quite often these ingestion rates were much higher than

466 those predicted by the equations, while at other times ingestion rates were much lower. This

467 might suggest that the quality of ice algae as a food source was highly variable. No enrichment

468 treatments were offered to the outer shelf copepods, Neocalanus and Eucalanus, because these

469 taxa were not encountered at locations where an ice algal bloom was present.

471 Corrections were made to account for trophic cascades in the grazing experiments that could 472 reduce the apparent mesozooplankton chlorophyll grazing rates because of the reduction of

473 microzooplankton grazing pressure in experimental relative to control jars (Nejstgaard et al.,

474 2001). These corrections could only be made for the subset of grazing experiments for which the

475 samples were enumerated for microzooplankton abundance/biomass and where paired dilution

476 assays to measure microzooplankton grazing were conducted. It is not surprising that the 
477 correction had the greatest impact for the mid shelf copepods and Metridia because of their

478 strong preference for microzooplankton (Table 5). The corrected grazing rates of mid shelf

479 copepods were 26 to $44 \%$ higher, while the outer shelf/slope copepods, with the exception of

480 Metridia, only increased by 3 to $15 \%$, and euphausiids by $4 \%$.

482 The total ingestion rate for this same sub-set of experiments was estimated by combining the 483 corrected chlorophyll ingestion rates and the ingestion of microzooplankton (Table 5). Again,

484 the mid shelf copepods and Metridia had the greatest proportional increase in total carbon

485 ingestion relative to ingestion based on corrected chlorophyll alone. Including microzooplankton

486 in the ingestion estimate further increased ingestion by 21 to $69 \%$ for mid shelf copepods and

487 only 3 to $10 \%$ for outer shelf/slope copepods and euphausiids. Total ingestion estimates more

488 than doubled relative to the uncorrected chlorophyll ingestion for Pseudocalanus spp. and

489 Acartia longiremis. By comparison, euphausiid total ingestion was only enhanced by about $14 \%$.

490

491 A comparison between the feeding rate responses predicted by the uncorrected versus corrected

492 chlorophyll ingestion and the corrected chlorophyll versus total ingestion (chlorophyll and

493 microzooplankton prey) were made for Calanus spp. C5-adults and euphausiids (Figure 8A-D).

494 There were not enough experiments enumerated for microzooplankton for the other

495 mesozooplankton taxa to produce reasonable functional relationships. The enhancement of

496 ingestion rates, not surprisingly, was greatest for Calanus spp., since this taxon had a stronger

497 preference for microzooplankton than euphausiids. Maximum ingestion rates $\left(\mathrm{V}_{\max }\right.$ with $\mathrm{R}^{2}$

498 values in parentheses) were $14(0.74), 17(0.82)$, and $18.5(0.83) \%$ body carbon day $^{-1}$ for

499 uncorrected chlorophyll, corrected chlorophyll, and total prey, respectively. In contrast, for 
500 euphausiids, which were non-selective feeders, there were only marginal increases in their

501 maximal ingestion rates, $3.1(0.28), 3.3(0.30)$, and $3.4(0.30) \%$ body carbon day ${ }^{-1}$ for

502 uncorrected chlorophyll, corrected chlorophyll, and total prey, respectively.

503

504 3.4. Grazing Impacts

505

506 The overall mean daily grazing impact on integrated chlorophyll biomass across all cruises and

507 all experiments was only $2.7 \% \pm 4.4 \%$, but an order of magnitude higher on integrated primary

508 production, $26 \% \pm 48 \%$. Uncorrected chlorophyll ingestion rates were used for these estimates

509 because corrected ingestion relationships were not available for all taxa. Therefore, these

510 estimates underestimate grazing impacts to some degree, likely more at inner and middle shelf

511 regions than the outer shelf because of the higher preference for microzooplankton by the

512 mesozooplankton community at those locations, and less at bloom than non-bloom locations

513 because the microzooplankton were a less important part of the diet.

515 Grazing impacts of mesozooplankton on chlorophyll standing stock and primary production were 516 compared between cruises, regions, domains, and bloom conditions (Table 6). Non-parametric

517 tests were used for all comparisons because the variance was unequal in most cases and also the

518 impact of outliers on the comparisons was reduced. Grazing impacts on chlorophyll standing

519 stock were extremely low in all cases. The impacts on primary production were much higher

520 than for chlorophyll standing stock. Mean grazing impacts on primary production in the South

521 region was more than double that in the North, and impacts in the Outer domain were three times

522 as high as those in the Inner and Middle domains, the latter appeared to be due to much higher 
523 zooplankton biomass in the Outer domain. However, neither of the comparisons was

524 significantly different because of the high variability of the measurements. Only the comparisons

525 between bloom and non-bloom conditions were significantly different. In bloom conditions

526 where primary production exceeded $1 \mathrm{gC} \mathrm{m}^{-2} \mathrm{~d}^{-1}$, grazing impacts were very low, on the order of

$527 \quad 8 \pm 16 \% \mathrm{~d}^{-1}$.

528

529 The highest impacts occurred at locations where the chlorophyll biomass and primary

530 productivity were low (Figure 9). During phytoplankton blooms the grazing impacts were

531 relatively insignificant. Comparisons between years indicate that the grazing impact on

532 chlorophyll standing stock was strongly correlated with the zooplankton biomass and the

533 coincident higher grazing rates (Figure 9, Table 6). It was lowest in 2008 when the zooplankton

534 biomass was lowest and highest in 2010 when the zooplankton biomass was more than three

535 times as high as the earlier years (Table 6). The 2010 research cruise occurred about a month

536 later than the 2008 and 2009 cruises, and the higher biomass likely reflects biomass accumulated

537 during the spring. The mean grazing impact on the integrated primary production by cruise

538 varied between 9 and 38\% per day (Table 6). The high rates observed in 2008 were driven by a

539 single outlier of $275 \%$ per day, where the measured primary production was extremely low.

540 Removing the outlier would result in a mean value for the cruise of $16 \%$, which is more similar

541 to 2009 and a much stronger relationship between zooplankton biomass and the proportion of the

542 primary production that was grazed (Figure 9).

543

544 4. Discussion

545 
546 Mesozooplankton feeding ecology was investigated on three, 6-week cruises to the Bering Sea

547 during which a large number of individual grazing determinations were conducted over a range

548 of sea ice and phytoplankton bloom conditions, at multiple cross-shelf and along-shelf (northern

549 vs. southern Bering Sea) locations and during both mid and late spring periods. This rich data

550 set demonstrated that Bering Sea zooplankton show differences in prey preference and ingestion

551 rate, that microzooplankton are preferred prey for several species, but that large phytoplankton

552 (diatoms) comprise the largest portion of the mesozooplankton diet in spring simply because

553 they are much more abundant than microzooplankton, that mesozooplankton readily ingest ice

554 algae as prey, and that mesozooplankton in these 'cold' years did not graze a substantial

555 proportion of the primary production or chlorophyll standing stock at most locations and

556 particularly in phytoplankton bloom regions.

557

558 4.1. Mesozooplankton Feeding During Spring Sea-ice Conditions

559

560 In these experiments, we do not know with certainty the reason a particular prey type is chosen

561 in preference to another. A prey type might be actively chosen or avoided because of many

562 reasons including size, swimming speed or behavior, nutritional quality, or toxicity. Or, it could

563 be that the zooplankter is incapable/inefficient at capturing a prey type because of many of the

564 same reasons. Here we are measuring the apparent prey preference because of these

565 uncertainties.

566

567 The types and proportions of prey in the diet of mesozooplankton depended on a combination of

568 their apparent prey type preference, prey size preference, and the relative abundances of different 
569 types and sizes in the ambient prey field. All mesozooplankton, including copepods and

570 euphausiids, preferentially fed on larger $(>5 \mu \mathrm{m})$ phytoplankton/ice algal cells as opposed to

571 smaller $(<5 \mu \mathrm{m})$ phytoplankton cells. These large cells were primarily diatoms, especially in the

572 bloom regions (Moran et al. 2012; Sherr et al. 2013). The few occasions when there appeared to

573 be a strong preference for smaller cells occurred at very low chlorophyll concentrations when

574 grazing rates were low and variability in the grazing estimates were high. However, for the most

575 part, even when smaller cells were relatively more abundant, larger cells were still preferred.

576 This may simply reflect cell-capturing capability as opposed to preference, as particles less than

577 about $5-\mu \mathrm{m}$ are too small to be grazed efficiently by many mesozooplankton (Berggreen et al.,

578 1988; Boyd et al., 1984; Fernandez, 1979; Nival and Nival, 1976).

579

580 Quite often many of the common mesozooplankton species, Calanus spp. for example, are

581 referred to as herbivores, but that is a misnomer. It has been shown that many copepods are

582 omnivorous, often preferring animal to plant food (Barthel, 1990, 1988; Campbell et al., 2009;

583 Gifford 1993; Stoecker and Capuzzo, 1990). All of the mesozooplankton included in our grazing

584 measurements were omnivorous to varying degrees, some such as the mid shelf copepods

585 Calanus spp. and Pseudocalanus spp. and the outer shelf/slope species Metridia pacifica,

586 strongly preferred microzooplankton, while the outer shelf/slope species Neocalanus

587 flemingeri/plumchrus and Eucalanus bungii and the euphausiids readily fed on them, but were

588 non-selective or preferred phytoplankton. In the Western Arctic Ocean, shelf copepods,

589 especially Pseudocalanus spp., and the slope copepod Metridia longa were also found to have a

590 strong preference for microzooplankton, while the Arctic Basin copepod Calanus hyperboreous

591 fed non-selectively (Campbell et al., 2009). However, the dominant shelf species, $C$. 
592 glacialis/marshallae, appeared to mostly feed non-selectively during spring, but strongly

593 preferred microzooplankton during summer when they were more abundant and the

594 phytoplankton was dominated by smaller cells (Hill et al., 2005). In the more oceanic regions of

595 the subarctic Pacific Ocean as well as in the Gulf of Alaska, Neocalanus and Eucalanus appeared

596 to have a stronger preference for microzooplankton than we found in the outer shelf regions of

597 our study for these species (Gifford, 1993; Liu et al., 2005; Mackas and Tsuda, 1999). Thus, the

598 degree of omnivory likely depends to a high degree on the food environment as well as the

599 mesozooplankton taxa.

600

601 There were differences in the preferences for the size and type of microzooplankton prey. Most

602 taxa significantly cleared larger microzooplankton at higher rates than small microzooplankton.

603 If there was a preference shown for the type of microzooplankton prey, it was for ciliates as

604 opposed to heterotrophic dinoflagellates, with both M. pacifica and euphausiids showing a strong

605 preference for ciliates (and Acartia longiremis in single experiment). It was not surprising that

606 M. pacifica had strong preferences for large microzooplankton and ciliates. This genus has very

607 selective feeding behavior. It has been shown to be more predatory than Calanus spp. (e.g.

608 Stevens et al., 2004) and has a highly variable, poorly predictable feeding response to

609 chlorophyll concentration (this study, Campbell et al., 2009). Batchelder (1986) concluded that

610 M. pacifica in the subarctic Pacific had a lower feeding rate on chlorophyll compared to similarly

611 sized crustaceans, which also might suggest that other food sources, such as microzooplankton

612 (including protists and small metazoans), must be an important component of the diet.

613 
614 Prey composition (type, size, nutritional quality) plays an important role in determining the type

615 and quantity of prey consumed by the mesozooplankton at different locations and times (e.g.

616 Campbell et al. 2009; Gifford et al. 1981; Huntley et al. 1987; Klein Breteler et al., 1999;

617 Kleppel 1993; Langdon and Waldock 1981; Mullin, 1963; Nival and Nival 1976; Stoecker and

618 Capuzzo, 1990; Støttrup and Jensen 1990). Although many mesozooplankton taxa preferred

619 microzooplankton to phytoplankton, when the prey field was dominated by large phytoplankton

620 cells, the mesozooplankton diet would contain a larger proportion of phytoplankton because that

621 prey type was much more abundant than the microzooplankton. Consequently, large diatom

622 cells were the dominant food source for the mesozooplankton in spring simply because the large

623 diatoms dominated the prey field biomass in the characteristic spring phytoplankton and ice algal

624 blooms.

625

626 Ice algae are likely an important source of food for many Arctic and subarctic zooplankton taxa

627 during early spring. In the Arctic, pelagic copepods including, Calanus glacialis and

628 Pseudocalanus spp., have been observed migrating up to the ice/water interface to feed on ice

629 algae (Conover et al., 1986; Runge and Ingram 1991, 1988). During our cruises on ice station

630 deployments, euphausiids also were observed in close association with the ice and appeared to be

631 feeding (R. Gradinger pers. comm.). The enriched treatments to which ice algal communities

632 were added to the ambient water demonstrated that if ice algal communities were available they

633 were readily ingested, but they cannot be used to quantify their importance in situ. However, it

634 appears that ice algae are an important early season food source for most mesozooplankton

635 because they can provide an early, highly-concentrated food source when the water column food

636 supply is severely limited. They can also extend the very short growing season, which may be 
637 critical for many species to complete their life cycles (e.g. Ji et al., 2012), and provide an energy

638 source for early reproduction (e.g. Daase et al., 2013; Søreide et al., 2010; ). It is critical then,

639 that new methods be developed to quantify the importance of ice algae as a food source for

640 mesozooplankton during the early spring to understand the food web dynamics of waters with

641 seasonal sea ice. Promising new approaches include the quantification of prey DNA in gut

642 contents of mesozooplankton (Durbin and Casas, 2014), and measurement of compound-specific,

643 stable carbon isotopes that can distinguish between prey, including separating phytoplankton and

644 ice algal food sources (Graham et al., 2014; Wang et al., 2013).

645

646 Estimating feeding rates from chlorophyll ingestion can provide a robust estimate of the energy

647 intake for most mesozooplankton during spring blooms in high latitude regions because the 648 majority of the ingested prey is chlorophyll based, in the form of phytoplankton or ice algae.

649 During summer, ingestion based on chlorophyll provides a much poorer estimate of total food

650 intake as smaller phytoplankton cells that are not grazed efficiently are more important and the

651 microzooplankton are more abundant and a larger portion of the diet (Campbell et al., 2009).

652 Ingestion estimates based on microscopic analysis can provide more information on the feeding

653 capabilities and preferences, the types and sizes of the preferred prey, but at the cost of higher

654 uncertainties in total prey consumption and much smaller number of ingestion estimates.

655 By focusing a large part of this study's effort on estimating size-fractioned chlorophyll ingestion

656 rates for as many of the dominant taxa as possible at each of the 50 process stations, 596 grazing

657 estimates were obtained over the course of the 3 year study. This high number of estimates that

658 covered a large range of chlorophyll concentrations allowed the determination of robust, 
659 predictive functional relationships despite the high variability in food quality that can occur in

660 natural assemblages compared with controlled laboratory studies.

661

662 It has been stated that trophic cascades in the experimental jars during grazing experiments can

663 reduce the estimates of chlorophyll ingestion by the mesozooplankton grazers (Nejstgaard et al.,

664 2001). This effect can be important when microzooplankton grazing-pressure is high and they

665 are a strongly preferred prey item of the mesozooplankton. Nejstgaard et al., (2001) proposed a

666 method to correct for trophic cascades in grazing experiments. To apply this correction, one has

667 to enumerate the microzooplankton in the grazing experiments and conduct parallel dilution

668 assays to estimate microzooplankton grazing on the same experimental water. This correction

669 could be made for about half of our grazing estimates, 304 out of 596 measurements. The degree

670 to which trophic cascades affected the grazing experiments depended on the strength of the

671 preference for microzooplankton prey by the mesozooplankton taxa. Chlorophyll grazing rates,

672 when corrected for trophic cascades, increased by over $40 \%$ for the strongly omnivorous

673 Pseudocalanus spp. and Metridia. pacifica. The grazing rates were only enhanced by between 3

674 and $15 \%$ for the outer shelf copepods that were the biomass dominants, which overall did not

675 have as strong a preference for microzooplankton prey. Likewise, average euphausiid grazing

676 rates were only enhanced by $4 \%$ when trophic cascades were accounted for in their estimates.

677 Without these corrections, grazing rates would likely be underestimated to a greater extent in

678 summer, when the chlorophyll distribution is skewed to smaller sizes (Lomas et al., 2012), and

679 the microzooplankton biomass is greater (Sherr et al., 2013; Stoecker et al., 2014). 
681 Even in spring when not yet very abundant, microzooplankton can contribute a significant 682 portion of the diet for many taxa. For M. pacifica and the mid shelf copepod species including 683 microzooplankton in the diet, on average, increased the total carbon ingested by about 20 to $40 \%$, 684 (69\% in the single experiment with $A$. longiremis), despite microzooplankton being a small 685 proportion of the prey field biomass. On average, the total ingested carbon was more than 686 double than what was estimated based on uncorrected chlorophyll ingestion alone for 687 Pseudocalanus spp. and A. longiremis. For the remaining outer shelf copepod species 688 (Neocalanus spp., E. bungii), the enhancement was only between 3 and $10 \%$ and for euphausiids $6897 \%$, all very similar to the proportion that microzooplankton contributed to the prey field 690 biomass. For Calanus and euphausiids there were enough experiments for which ingestion of 691 microzooplankton were determined to allow us to fit ingestion relationships to the data. It was 692 clear that not correcting for trophic cascades, and not including microzooplankton in the diet 693 greatly underestimated the total carbon ingestion for Calanus. The maximum predicted 694 chlorophyll ingestion rate was increased by $21 \%$ body carbon day ${ }^{-1}$ for Calanus, but only $6 \%$ 695 body carbon day ${ }^{-1}$ for euphausiids. By including microzooplankton in the diet, the total carbon 696 intake for Calanus increased over the uncorrected chlorophyll ingestion by $32 \%$ body carbon 697 day $^{-1}$, while for euphausiids the increase was less than $10 \%$ body carbon day ${ }^{-1}$. For the more 698 strongly selective taxa it is important to both correct for trophic cascades and include the 699 ingestion of microzooplankton in the diet to obtain an accurate estimate of total energy intake. 
703 The mesozooplankton grazing impacts during spring were generally very low. Mesozooplankton

704 could crop a substantial portion of the chlorophyll biomass/production only when the chlorophyll

705 biomass/production rates were low or when the mesozooplankton biomass was high, as occurred

706 mainly for the late spring cruise in 2010. Overall, the mean copepod grazing impacts on

707 integrated chlorophyll biomass was very low $\left(2.7 \pm 4.4 \% \mathrm{~d}^{-1}\right)$; while that for integrated primary

708 production was much higher $\left(26 \pm 48 \% \mathrm{~d}^{-1}\right)$. However, for both impact measures the impacts

709 were strongly skewed with high impacts only at the lowest chlorophyll biomass or primary

710 production rates. During bloom conditions grazing impacts were on average very low: $<8 \%$ of

711 the primary production was grazed. It should be emphasized that it is not the average grazing

712 impacts during spring that are important for determining the strength of benthic-pelagic coupling,

713 but rather the impacts during the ice-edge blooms where most of the spring production occurs.

714

715 Dagg et al. (1982) found that mesozooplankton grazing impacts on the southern Bering Sea shelf

716 in May were similar in magnitude to our estimates; 18,25 , and $6 \%$ of the primary production

717 was grazed in the outer, mid and coastal regions, respectively, despite encountering much

718 warmer water temperatures of around $6{ }^{\circ} \mathrm{C}$. Their study also determined grazing rates from

719 bottle incubations and mesozooplankton biomass from $60-\mathrm{cm}$ Bongo net hauls. These grazing

720 impacts, like ours, were likely underestimates because euphausiids are difficult to assess by any

721 means and can avoid collection by nets (Hunt et al., this volume; Sameoto et al., 1993; Wiebe et

722 al., 2013). Thus the euphausiid contribution to the grazing impacts was underestimated to some

723 unknown degree in both studies.

724 
725 Euphausiids only accounted for 12 to $15 \%$ of the mean, spring, mesozooplankton biomass and 3

726 to $6 \%$ of the grazing impacts in our study likely because their true biomass was severely

727 underestimated. Hunt et al. (this volume) in a synthesis of net tow samples, acoustic data, and

728 model output from recent years estimated the euphausiid biomass in the eastern Bering Sea for

729 different regions and seasons. In spring, based on model output, mean biomass between 2004

730 and 2009 was 2,140 and 2,610 $\mathrm{m} \mathrm{C} \mathrm{m}^{-2}$ for the middle and outer domains, with a mean value of

$7312,475 \mathrm{mg} \mathrm{C} \mathrm{m}^{-2}$. In contrast, based on our bongo net samples we estimated mean krill biomass,

732 on the shelf in spring, to be $47 \pm 83,132 \pm 125$, and $167 \pm 144 \mathrm{mg} \mathrm{C} \mathrm{m}^{-2}$ in 2008,2009 , and 2010,

733 respectively, about $15-50$ fold lower than Hunt et al.'s (this volume) mean estimate. If we

734 assume that euphausiid biomass at all locations in spring was equal to the average value of Hunt

735 et al. (this volume) then euphausiids would dominate the biomass of the mesozooplankton in

736 spring (63-86\% of total biomass across the three years). This is consistent with Vidal and

737 Smith's (1986) findings for the middle domain in spring. Euphausiid grazing impacts, however,

738 would increase to only 32 to $51 \%$ of the total impact across all years because of their lower

739 weight-specific ingestion rates. With these new estimates, mesozooplankton grazing-impacts

740 would increase to only 1 to $6 \%$ of the chlorophyll standing stock on average across all years. The

741 grazing impacts on primary production would increase to between 12 to $84 \%$ (to only $41 \%$ if a

742 single high outlier is excluded) on average across the years. However, the overall grazing impact

743 on primary production in bloom regions still would only be $10 \%$ of the total production.

744

745 The eastern Bering Sea shelf can be characterized as having a benthic-dominated region in the

746 north and a pelagic-dominated region in the south (Grebmeier et al., 2006). These two regions

747 are separated by a transition zone occurring at about $60^{\circ} \mathrm{N}$ (Stabeno et al., 2012a, 2012b). In the 
748 north region, permanently cold bottom waters on the middle shelf limits the northern distribution

749 of demersal fish and invertebrate predators, which reduces predation and allows the benthic

750 community to flourish (Grebmeier et al., 2006; Wyllie-Echeverria and Wooster, 1998). Earlier

751 studies suggested that stronger benthic-pelagic coupling in the north compared to the south might

752 also contribute to the higher benthic biomass in the north (Springer et al., 1989). However, the

753 Oscillating Control Hypothesis suggested that at least for the southern region the connections are

754 more complicated, with strong benthic-pelagic coupling in cold regimes and weaker coupling in

755 warm regimes (Hunt et al., 2002). Here we directly determined the strength of benthic-pelagic

756 coupling in spring by measuring the potential grazing impacts of the dominant mesozooplankton

757 grazers across north and south regions for three consecutive spring seasons during a 'cold' period

758 in the Bering Sea and did not find any significant differences between the regions. There

759 appeared to be higher grazing impacts in the south, but these were not significantly different

760 because of high variability. Furthermore, the grazing impacts were extremely low at all bloom

761 locations where most of the spring production occurred. Benthic-pelagic coupling appears to be

762 strong in spring across the entire shelf at least during cold periods. Whether or not benthic-

763 pelagic coupling is weakened, with more of the production retained in the pelagial during warm

764 periods, remains an open question. If the extremely high grazing impacts of microzooplankton

765 measured during summer months, which often exceeded primary production (Stoecker et al.,

766 2014), is an indication of the potential for warm spring periods then the strength of benthic-

767 pelagic coupling in the south during warm periods could be much weaker.

768

769 On the eastern Bering Sea shelf, it appears that only about $50 \%$ of the primary production is

770 grazed during spring blooms during 'cold years'. Microzooplankton grazing accounted for about 
$77140 \%$ of phytoplankton daily growth at bloom locations as measured in dilution assays that were

772 paired with our experiments (Sherr et al., 2013), while our maximum estimates would suggest

773 that only about $10 \%$ of the production is grazed by the mesozooplankton, including krill. Thus it

774 would appear that in spring about half of the production would remain un-grazed and available

775 for export to the benthic communities. This is consistent with estimates of $e$-ratios for the Bering

776 Sea shelf in spring of about 50\% (Moran et al., 2012). In contrast, during summer,

777 microzooplankton grazing in the Bering Sea is much greater, exceeding phytoplankton growth in

778 the inner and middle domains (Stoecker et al., 2014). Unfortunately, mesozooplankton grazing

779 rates were not determined in summer as part of the Bering Sea project and so we do not know

780 whether mesozooplankton might reduce microzooplankton grazing-pressure through top-down

781 control given much higher mesozooplankton biomass in summer (Eisner et al., 2014; Vidal and

782 Smith, 1986; see BEST MOCNESS net tow data sets at the EOL Data archive:

783 http://www.eol.ucar.edu/projects/best) and strong preference for microzooplankton prey.

784

785 4.3. Summary

786

787 Eastern Bering Sea mesozooplankton were omnivorous, with most preferring

788 microzooplankton over chlorophyll (phytoplankton/ice algae). The strength of the

789 preference was taxon-specific.

790 - Despite a strong preference for microzooplankton, phytoplankton comprised the

791 dominant portion of the diet for all mesozooplankton taxa in spring blooms because its

792 biomass was much greater than that of the microzooplankton. 
- There were no significant differences in grazing impacts between regions or domains in spring: differences in trophic structure between the pelagically-dominated southern shelf and the benthically-dominated northern shelf could not be attributed to differences in planktonic grazing pressure at least for the three 'cold years' of this study.

- Grazing impacts were low in spring phytoplankton blooms during 'cold years'. Only about $50 \%$ of the primary production in the blooms was grazed by the combined efforts of the micro- and mesozooplankton communities.

801 Acknowledgements

803 We would like to express our appreciation to the captains, crews, and science support teams of 804 the USCGC Healy and the R/V Thomas G. Thompson for their support during the BEST cruises.

805 We would also like to thank C. Mordy and the BEST CTD service team for help with water 806 sample collection and nutrient analysis. We are indebted to our BEST-BSIERP colleagues for 807 support at sea and helpful discussions during project meetings. Enumeration of the 808 mesozooplankton samples was conducted under contract by the Atlantic Reference Center, 809 Huntsman Marine Science Center, St. Andrews, New Brunswick under the direction of Dr.

810 Gerhard Pohle. Finally, we greatly appreciate the most helpful comments of three anonymous 811 reviewers and the editor, J. Napp. Funding for this project was provided by NSF grants ARC8120732362 to R. Campbell, ARC-0732382 to C. Ashjian, ARC-0732301 to E. and B. Sherr, and 813 ARC-0732359 to M. Lomas. This is BEST-BSIERP Bering Sea Project publication number 174. 


\section{References}

817

818 Baier, C.T., Napp, J.M., 2003. Climate-induced variability in Calanus marshallae populations.

819 J. Plankt. Res. 25, 771-782.

820

821 Bailey, K.M., Dunn, J., 1979. Spring and summer foods of walleye pollock, Theragra

822 chalcogramma, in the eastern Bering Sea. Fish. Bull. 77, 304-308.

823

824 Barthel, K.-G., 1990. Relationships of food uptake and body components of Calanus

825 finmarchicus, C. glacialis, and C. hyperboreous to particulate matter and water characteristics in

826 Fram Strait. Polar Biol. 10, 343-350.

827

828 Barthel, K-G., 1988. Feeding of three Calanus species on different phytoplankton assemblages

829 in the Greenland Sea. Meeresforsh. 32, 92-106.

830

831 Batchelder, H.P. 1986. Phytoplankton balance in the oceanic subarctic Pacific: grazing impact of

832 Metridia pacifica. Mar. Ecol. Prog. Ser. 34, 213-225.

833

834 Berggreen, U., Hansen, B., Kiørboe, T., 1988. Food size spectra, ingestion and growth of the

835 copepod Acartia tonsa during development: implications for determination of copepod

836 production. Mar. Biol. 99 (3), 341-352.

837 
838 Boyd, C.M., Heyraud, M., Boyd, C.N., 1984. Feeding of the Antarctic krill Euphausia superba. J.

839 Crustacean Biol. 4(1), 123-141.

840

841 Brodeur, R.D., Wilson, M.T, Ciannelli, L., Doyle, M., Napp, J.M., 2002. Interannual and

842 regional variability in distribution and ecology of juvenile pollock and their prey in frontal

843 structures of the Bering Sea. Deep-Sea Res. 49, 6051-6067.

844

845 Campbell, R. G., Sherr, E. B., Ashjian, C. J., Plourde, S., Sherr, B. F., Hill, V., Stockwell, D. A., 846 2009. Mesozooplankton prey preference and grazing impact in the western Arctic Ocean. Deep 847 Sea Res. II 56(17), 1274-1289.

848

849 Ciannelli, L., Brodeur, R.D., Napp, J.M., 2004. Foraging impact on zooplankton by age-0

850 walleye pollock (Theragra chalcogramma) around a front in the southeast Bering Sea. Mar. Biol. $851 \quad 144,515-526$.

852

853 Coachman, L. K., 1986. Circulation, water masses, and fluxes on the southeastern Bering Sea 854 Shelf. Cont. Shelf Res. 5, 23-108.

855

856 Conover, R.J, Herman, A.W., Prinsenberg, S.J, Harris, L.R., 1986. Distribution of and feeding by 857 the copepod Pseudocalanus under fast ice during the Arctic spring. Science 232, 1245-1247.

858

859 Cooney, R.T., Coyle, K.O., 1982. Trophic implications of cross-shelf copepod distributions in 860 the southeastern Bering Sea. Mar. Biol. 70, 187-196. 
862 Coyle, K. O., Eisner, L. B., Mueter, F. J., Pinchuk, A. I., Janout, M. A., Cieciel, K. D., Farley,

863 E.V., Andrews, A. G., 2011. Climate change in the southeastern Bering Sea: impacts on pollock

864 stocks and implications for the oscillating control hypothesis. Fish. Oceanogr. 20(2), 139-156.

865

866 Coyle, K.O., Pinchuk, A.I., 2002. Climate-related differences in zooplankton density and growth

867 on the inner shelf of the southeastern Bering Sea. Prog. Oceanogr. 55, 177-194.

868

869 Daase, M., Falk-Petersen, S., Varpe, Ø., Darnis, G., Søreide, J. E., Wold, A., Leu, E., Berge, J.,

870 Philippe, B., Fortier, L., 2013. Timing of reproductive events in the marine copepod Calanus

871 glacialis: a pan-Arctic perspective. Can. J. Fish. Aquat. Sci. 70(6), 871-884.

872

873 Dagg, M., 1993. Sinking particles as a possible source of nutrition for the large calanoid

874 copepod Neocalanus cristatus in the subarctic Pacific Ocean. Deep-Sea Res. I 40, 1431-1445.

875

876 Dagg, M.J., Vidal, J., Whitledge, T.E., Iverson, R.L., Goering, J.J., 1982. The feeding,

877 respiration, and excretion of zooplankton in the Bering Sea during a spring bloom. Deep-Sea

878 Res. I 29, 45-63.

879

880 Durbin, E.G., Casas, M.C., 2014. Early reproduction by Calanus glacialis in the Northern Bering 881 Sea: the role of ice algae as revealed by molecular analysis. J. Plankton Res. 36(2), 523-541. 882 
883 Dwyer, D.A., Bailey, K.M., Livingston, P.A., 1987. Feeding habits and daily ration of walleye 884 pollock (Theragra chalcogramma) in the eastern Bering Sea, with special reference to 885 cannibalism. Can. J. Fish. Aquat. Sci. 44, 1872-1984.

886

887 Eisner, L. B., Napp, J. M., Mier, K. L., Pinchuk, A. I., \& Andrews, A. G., 2014. Climate-

888 mediated changes in zooplankton community structure for the eastern Bering Sea. Deep Sea Res. 889 II 109, 157-171.

890

891 Fernández, F., 1979. Particle selection in the nauplius of Calanus pacificus. J. Plankton Res. 1 892 (4), 313-328.

893

894 Frost, B.W., 1972. Effects of size and concentration of food particles on the feeding behavior of 895 the marine planktonic copepod Calanus pacificus. Limnol. Oceanogr. 17 (6), 805-815.

896

897 Gifford, D.J., 1993. Protozoa in the diets of Neocalanus spp. in the oceanic Subarctic Pacific 898 Ocean. Prog. Oceanogr. 32, 223-237.

899

900 Gifford, D.J., Bohrer, R.N., Boyd, C.M., 1981. Spines on diatoms: Do copepods care? Limnol.

901 Oceanogr. $26(6), 1057-1061$.

902

903 Graham, C., Oxtoby, L., Wang, S.W., Budge, S.M., Wooller, M.J., 2014. Sourcing fatty acids to 904 juvenile polar cod (Boreogadus saida) in the Beaufort Sea using compound-specific stable 905 carbon isotope analyses. Polar Biol. 37(5), 697-705. 
907 Grebmeier, J.M., Overland, J.E., Moore, S.E., Farley, E.V., Carmack, E.C., Cooper, L.W., Frey,

908 K.E., Helle, J.H., McLaughlin, F.A., McNutt, S.L. 2006. A major ecosystem shift in the northern

909 Bering Sea. Science 311: 1461-1464.

910

911 Heintz, R. A., Siddon, E. C., Farley, E. V., Napp, J. M. 2013. Correlation between recruitment

912 and fall condition of age-0 pollock (Theragra chalcogramma) from the eastern Bering Sea under

913 varying climate conditions. Deep-Sea Res. II 94, 150-156.

914

915 Hill, V., Cota, G., \& Stockwell, D., 2005. Spring and summer phytoplankton communities in the

916 Chukchi and Eastern Beaufort Seas. Deep-Sea Res. II 52(24), 3369-3385.

917

918 Hunt, G. L., Coyle, K. O., Eisner, L. B., Farley, E. V., Heintz, R. A., Mueter, F., Napp, J.M.,

919 Overland, J.E., Ressler, P.H., Salo, S., Stabeno, P. J., 2011. Climate impacts on eastern Bering

920 Sea food webs: a synthesis of new data and an assessment of the Oscillating Control

921 Hypothesis. ICES J. Mar. Sci.: J. Cons. 68(6), 1230-1243.

922

923 Hunt, G.L. Jr., Stabeno, P., Walters, G., Sinclair, E., Brodeur, R.D., Napp, J.M., Bond, N.A.,

924 2002. Climate change and control of the southeastern Bering Sea pelagic ecosystem. Deep-

925 Sea Res. II 49, 5821-5853.

926

927 Hunt, G.L., Ressler, P.H., Gibson, G., De Robertis, A., Aydin, K., Sigler, M.F., Ortiz, I., Lessard, 928 E.J., Williams, B., Pinchuk, A., Buckley, T. (This Issue). Euphausiids in the Eastern Bering Sea: 
929 A synthesis of recent studies of euphausiid production, consumption and population control.

930 Deep-Sea Res. II.

931

932 Huntley, M.E., Ciminiello, P., Lopez, M.D.G., 1987. Importance of food quality in determining

933 development and survival of Calanus pacificus (Copepoda: Calanoida). Mar. Biol. 95, 103-113.

934

935 Iverson, R.L, Whitledge, T.E., Goering, J.J., 1979. Chlorophyll and nitrate fine structure in the

936 southeastern Bering Sea shelf break front. Nature 281, 664-666.

937

938 Jacobs, J., 1974. Quantitative measurement of food selection. Oecologia 14(4), 413-417.

939

940 Ji, R., Ashjian, C. J., Campbell, R. G., Chen, C., Gao, G., Davis, C. S., Cowles, G.W., Beardsley,

941 R. C., 2012. Life history and biogeography of Calanus copepods in the Arctic Ocean: An

942 individual-based modeling study. Prog. Oceanogr. 96(1), 40-56.

943

944 Kleiber, M., 1947. Body size and metabolic rate. Physiol. Rev. 27(4), 511-541.

945

946 Klein Breteler, W.C.M., Schogt, N., Baas, M., Schouten, S., Kraay, G.W., 1999. Trophic

947 upgrading of food quality by protozoans enhancing copepod growth: role of essential lipids. Mar.

948 Biol. 135, 191-198.

949

950 Kleppel, G.S. 1993. On the diets of calanoid copepods. Mar. Ecol. Prog. Ser. 99, 183-195. 951 
952 Landry, M.R., 1993. Estimating rates of growth and grazing mortality of phytoplankton by the

953 dilution method, p. 715-722. In P.F. Kemp, B.F. Sherr, E.B. Sherr and J.J. Cole (eds.), Handbook

954 of Methods in Aquatic Microbial Ecology. Lewis Publ., Boca Raton, FL.

955

956 Langdon, C.J., Waldock, M.J., 1981. The effect of algal and artificial diets on the growth and

957 fatty acid composition of Crassostrea gigas spat. J. Mar. Biol. Assoc. U.K. 61, 431-448.

958

959 Liu, H., Dagg, M. J., \& Strom, S. 2005. Grazing by the calanoid copepod Neocalanus cristatus

960 on the microbial food web in the coastal Gulf of Alaska. J. Plankton Res. 27(7), 647-662.

961

962 Lomas, M. W., Moran, S. B., Casey, J. R., Bell, D. W., Tiahlo, M., Whitefield, J., Kelly, R.P.,

963 Mathis, J.T., Cokelet, E. D., 2012. Spatial and seasonal variability of primary production on the

964 Eastern Bering Sea shelf. Deep-Sea Res. II 65, 126-140.

965

966 Mackas, D. L., \& Tsuda, A., 1999. Mesozooplankton in the eastern and western subarctic

967 Pacific: community structure, seasonal life histories, and interannual variability. Prog. Oceanogr.

$96843(2), 335-363$.

969

970 Menden-Deuer, S., Lessard, E. J. 2000. Carbon to volume relationships for dinoflagellates,

971 diatoms, and other protist plankton. Limnol. Oceanogr. 45(3), 569-579.

972 
973 Moore, S.E., Waite, J.M., Friday, N.A., Honkaleho, T., 2002. Cetacean distribution and relative

974 abundance on the central-eastern and the southeastern Bering Sea shelf with reference to

975 oceanographic domains. Prog. Oceanogr. 55, 249-261.

976

977 Moran, S.B., Lomas, M.W., Kelly, R.P., Gradinger, R., Iken, K., Mathis, J.T. 2012. Seasonal

978 succession of net primary productivity, particulate organic carbon export, and autotrophic

979 community composition in the eastern Bering Sea. Deep-Sea Res. II 65, 84-97.

980

981 Mullin, M.M., 1963. Some factors affecting the feeding of marine copepods of the genus

982 Calanus. Limnol. Oceanogr. 8, 239-250.

983

984 Nejstgaard, J.C., Naustvoll, L.-J., Sazhin, A., 2001. Correcting for underestimation of

985 microzooplankton grazing in bottle incubation experiments with mesozooplankton. Mar. Ecol.

986 Prog. Ser. 221, 59-75.

987

988 Nival, P., Nival, S., 1976. Particle retention efficiencies of an herbivorous copepod, Acartia

989 clausi (adult and copepodite stages): effects on grazing. Limnol. Oceanogr. 21 (1), 24-38.

990

991 Ohman, M.D., Runge, J.A., 1994. Sustained fecundity when phytoplankton resources are in short

992 supply: omnivory by Calanus finmarchicus in the Gulf of St. Lawrence. Limnol. Oceanogr. 39, $99321-36$.

994 
995 Putt, M., Stoecker, D. K. 1989. An experimentally determined carbon: volume ratio for marine

996 "oligotrichous" ciliates from estuarine and coastal waters. Limnol. Oceanogr. 34(6), 1097-1103.

998 Rivkin, R.B., Legendre L., Diebel D., et al., 1996. Vertical flux of biogenic carbon in the ocean:

999 is there food web control? Science 272,1163-1166.

1000

1001 Runge, J.A., Ingram, R.G., 1991. Under-ice feeding and diel migration by the planktonic

1002 copepods Calanus glacialis and Pseudocalanus minutus in relation to the ice algal production

1003 cycle in southeastern Hudson Bay, Canada. Mar. Biol. 108, 217-225.

1004

1005 Runge, J.A., Ingram, R.G., 1988. Under-ice grazing by planktonic, calanoid copepods in relation 1006 to a bloom of ice microalgae in southeastern Hudson Bay. Limnol. Oceanogr. 33, 280-286.

1008 Runge, JA., Therriault, J.-C., Legendre, L., Ingram, R.G., Demers, S., 1991. Coupling between

1009 ice microalgal productivity and the pelagic, metazoan food web in the southeastern Hudson Bay:

1010 A synthesis of results. Polar Res. 10 (2), 325-338.

1011

1012 Sameoto, D., Cochrane, N., Herman, A., 1993. Convergence of acoustic, optical, and net-catch 1013 estimates of euphausiid abundance - use of artificial-light to reduce net avoidance. Can. J. Fish.

1014 Aquat. Sci. 50, 334-346.

1015

1016 Schumacher, J. D., Stabeno, P.J., 1998. Continental shelf of the Bering Sea. In The Sea. Vol. 11, 1017 The global coastal ocean: Regional studies and synthesis, ed. A. R. Robinson, and K. H. Brink, 
1018 789-822. New York: John Wiley and Sons. 1704 pp.

1019

1020 Sherr, E. B., Sherr, B. F., Ross, C., 2013. Microzooplankton grazing impact in the Bering Sea

1021 during spring sea ice conditions. Deep-Sea Res. II 94, 57-67.

1022

1023 Sigler, M. F., Harvey, H. R., Ashjian, J., Lomas, M. W., Napp, J. M., Stabeno, P. J., \& Van Pelt,

1024 T. I., 2010. How does climate change affect the Bering Sea ecosystem? Eos, Trans. Am.

1025 Geophys.Union 91(48), 457-458.

1026

1027 Sigler, M. F., Stabeno, P. J., Eisner, L. B., Napp, J. M., \& Mueter, F. J., 2013. Spring and fall

1028 phytoplankton blooms in a productive subarctic ecosystem, the eastern Bering Sea, during 1995-

1029 2011. Deep-Sea Res. II 109, 71-83.

1030

1031 Smith, S.L., 1991. Growth, development and distribution of the euphausiids Thysanoessa raschii

1032 (M. Sars) and Thysanoessa inermis (Krøyer) in the southeastern Bering Sea. Polar Res. 10, 4611033478.

1034

1035 Smith, S.L., Vidal, J., 1984. Spatial and temporal effects of salinity, temperature and chlorophyll 1036 on the communities of zooplankton in the southeastern Bering Sea. J. Mar. Res. 42, 221-257.

1037

1038 Smith, S.L, Vidal, J., 1986. Variations in the distribution, abundance, and development of

1039 copepods in the southeastern Bering Sea in 1980 and 1981. Cont. Shelf. Res. 5, 215-239.

1040 
1041 Søreide, J.E., Leu, E., Berge, J., Graeve, M., Falk-Petersen, S., 2010. Timing of blooms, algal

1042 food quality and Calanus glacialis reproduction and growth in a changing Arctic. Glob. Chang.

1043 Biol. 16(11), 3154-3163.

1044

1045 Springer, A.M., McRoy, C.P., Turco, K.R., 1989. The paradox of pelagic food webs in the

1046 northern Bering Sea - II. Zooplankton communities. Cont. Shelf. Res. 9, 359-386.

1047

1048 Springer, A.M., Roseneau, D.G., 1985. Copepod-based food webs: auklets and oceanography in 1049 the Bering Sea. Mar. Ecol. Prog. Ser. 21, 229-237.

1050

1051 Stabeno, P.J., Bond, N.A., Kachel, N.B., Salo, S.A., Schumacher, J.D., 2001. On the temporal

1052 variability of the physical environment over the south-eastern Bering Sea. Fish. Oceanogr. 10, $105381-98$.

1054

1055 Stabeno, P.J., Farley, E.V., Jr., Kachel, N.B., Moore, S., Mordy, C.W., Napp, J.M., Overland, 1056 J.E., Pinchuk, A.I., Sigler, M.F. 2012a. A comparison of the physics of the northern and 1057 southern shelves of the eastern Bering Sea and some implications for the ecosystem. Deep-Sea 1058 Res. II 65-70: 14-30.

1059

1060 Stabeno, P.J., Kachel, N.B., Moore, S.E., Napp, J.M., Sigler, M., Yamaguchi, A., Zerbini, A.N., 1061 2012b. Comparison of warm and cold years on the southeastern Bering Sea shelf and some 1062 implications for the ecosystem. Deep-Sea Res. II 65-70: 31-45.

1063 
1064 Stevens, C.J., Deibel, D., Parrish, C.C., 2004. Copepod omnivory in the North Water Polynya

1065 (Baffin Bay) during autumn: spatial patterns in lipid composition. Deep-Sea Res. I 51 (11),

$1066 \quad 1637-1658$.

1067

1068 Stockwell, D.A., Whitledge, T.E., Zeeman, S.I., Coyle, K.O., Napp, J.M., Brodeur, R.D.,

1069 Pinchuk, A.I., Hunt, Jr. G. L., 2001. Anomalous conditions in the south-eastern Bering Sea,

1070 1997: Nutrients, phytoplankton, and zooplankton. Fish. Oceanogr. 10, 99-116.

1071

1072 Stoecker, D.K. Capuzzo, J. McD., 1990. Predation on protozoa: its importance to zooplankton. J.

1073 Plank. Res. 12, 891-908.

1074

1075 Stoecker, D. K., Weigel, A., Goes, J. I. 2014. Microzooplankton grazing in the Eastern Bering

1076 Sea in summer. Deep-Sea Res. II 109, 145-156.

1077

1078 Støttrup, J.G., Jensen, J., 1990. Influence of algal diet on feeding and egg-production of the

1079 calanoid copepod Acartia tonsa Dana. Journal of Experimental Mar. Biol. and Ecology 141, 87-

1080105.

1081

1082 Tourangeau, S., Runge J.A., 1991. Reproduction of Calanus glacialis in relation to an ice

1083 microalgal bloom in southeastern Hudson Bay, Canada. Mar. Biol. 106, 227-234

1084 
1085 Tynan, C.T., 2004. Cetacean populations on the SE Bering Sea shelf during the late 1990s:

1086 implications for decadal changes in ecosystem structure and carbon flow. Mar. Ecol. Prog. Ser.

$1087 \quad 272,281-300$.

1088

1089 Tynan, C.T., DeMaster, D.P. Peterson, W.T., 2001. Endangered right whales on the

1090 southeastern Bering Sea Shelf. Science 294, 1894.

1091

1092 Tynan, C.T., 2004. Cetacean populations on the SE Bering Sea shelf during the late 1990s:

1093 implications for decadal changes in ecosystem structure and carbon flow. Mar. Ecol. Prog. Ser.

$1094272,281-300$.

1095

1096 Vidal, J., Smith, S.L., 1986. Biomass, growth, and development of populations of herbivorous

1097 zooplankton in the southeastern Bering Sea during spring. Deep-Sea Res. 33, 523-556.

1098

1099 Wang, S.W., Budge, S.M., Gradinger, R.R., Iken, K., Wooller, M.J., 2013. Fatty acid and stable

1100 isotope characteristics of sea ice and pelagic particulate organic matter in the Bering Sea: tools

1101 for estimating sea ice algal contribution to Arctic food web production. Oecologia 1-14.

1102

1103 Welschmeyer, N. A., 1994. Fluorometric analysis of chlorophyll a in the presence of chlorophyll

1104 b and phaeopigments. Limnol. Oceanogr. 39(8), 1985-1992.

1105

1106 Wiebe, P.H., Lawson, G.L., Andone C., et al., 2013. Improved agreement of net and acoustical

1107 methods for surveying euphausiids by mitigating avoidance using a net-based LED strobe light 
1108 system. ICES J. Mar. Sci. 70, 650-664.

1109

1110 Wyllie - Echeverria, T. I. N. A., Wooster, W. S. 1998. Year - to - year variations in Bering Sea

1111 ice cover and some consequences for fish distributions. Fish. Oceanogr. 7(2), 159-170.

1112

1113 Zeuthen, E., 1953. Oxygen uptake as related to body size in organisms. Q. Rev. Biol. 28, 1-12.

1114

1115

1116

1117

1118

1119

1120

1121

1122

1123

1124

1125

1126

1127

1128

1129

1130 


\section{Figure Captions}

1132

1133 Figure 1. Station locations of grazing experiments in the eastern Bering Sea during spring.

1135 Figure 2. Prey field. The proportion of chlorophyll a $>5 \mu \mathrm{m}$ (left) and proportion of

1136 microzooplankton carbon of the total carbon in the prey field (right) vs. chlorophyll $a$

1137 concentration in the experimental water.

1138

1139 Figure 3. Diet vs. prey field comparisons for all mesozooplankton species combined. (Left) The

1140 proportion of chlorophyll $a(>5 \mu \mathrm{m})$ in the diet vs. the prey field, and (Right) the proportion of

1141 microzooplankton biomass in the diet vs. the prey field, with diet proportions corrected for

1142 trophic cascades. Dashed lines indicate the 1:1 relationship or no preference.

1143

1144 Figure 4. Importance of microzooplankton in the diet as it relates to chlorophyll ingestion rate.

1145 The proportion of microzooplankton in the diet vs. chlorophyll ingestion rate is shown for (Left)

1146 Calanus glacialis/marshallae adult females and (Right) all euphausiids (juveniles and adults).

1147 Values corrected for trophic cascades.

1148

1149 Figure 5. Diet and prey field comparison for different taxa. The proportion of microzooplankton

1150 in the prey field and diet are compared for each taxon. Asterisks indicate statistically significant

1151 differences between prey field and diet. Statistical comparisons are provided in Table 2. Values 1152 corrected for trophic cascades.

1153 
1154 Figure 6. Maximum ingestion rate versus body size. The maximum ingestion rate (Vmax) from

1155 the carbon ingestion rate vs. total chlorophyll relationships is plotted against the mean carbon

1156 content for the 8 species/stage groupings in Table 4. Values not corrected for trophic cascades.

1157 Each point is labeled by the species initials and dominant stage $(\mathrm{f}=$ female; $\mathrm{c}=$ copepodid$)$. The

1158 value for all euphausiids (Krill) is shown, not Thysanoessa raschii only.

1159

1160 Figure 7. Ingestion rate relationships. The mean ingestion rates for each experiment as a

1161 function of the initial chlorophyll $a(>5 \mu \mathrm{m})$ concentration for ambient and enriched treatments

1162 are shown for A) Calanus spp. (C5-adult), B) Calanus spp. (C1-C4), C) Pseudocalanus spp.

1163 (adult female), D) Metridia pacifica (adult female), E) Neocalanus flemingeri/plumchrus (C4,

1164 C5), F) Neocalanus cristatus (C5), G) Eucalanus bungii (C5, adult female), and H) Thysanoessa

1165 spp. (Juvenile, adult). Relationships for Michaelis-Menten equations were fit to the ambient

1166 values only. Parameter estimates are given in Table 4. Values not corrected for trophic cascades.

1168 Figure 8. Ingestion rate comparisons. Ingestion rates (percent body carbon) as a function of the

1169 initial chlorophyll $a$ or prey field carbon concentration for the subset of experiments where

1170 chlorophyll and microzooplankton ingestion rates were determined for Calanus spp. (C5-adult,

1171 A, C) and Thysanoessa spp. (juvenile and adult, B, D). Uncorrected chlorophyll and corrected

1172 chlorophyll (Nejstgaard et al. (2001) correction for trophic cascades) ingestion rates are shown in

1173 A and B. Corrected chlorophyll and total carbon ingestion (corrected chlorophyll and

1174 microzooplankton) are shown in C and D. Michaelis-Menten curve fits are shown for each data

1175 set.

1176 
1177 Figure 9. Grazing Impacts. A, B) The proportion of chlorophyll $a$ standing stock and primary

1178 production grazed in terms of the integrated chlorophyll and primary production. C, D) The

1179 proportion of chlorophyll $a$ standing stock and primary production grazed in terms of

1180 zooplankton biomass. Linear regressions for the proportion of chlorophyll $\left(\mathrm{R}^{2}=0.75 ; \mathrm{p}<0.0001\right)$

1181 and primary production $\left(\mathrm{R}^{2}=0.36 ; \mathrm{p}<0.0001\right)$, excluding the outlier of $275 \%$, grazed vs.

1182 zooplankton biomass are shown. Values not corrected for trophic cascades. 
1217 Figure 1.

1218

1219

1220

1221

1222

1223

1224

1225

1226

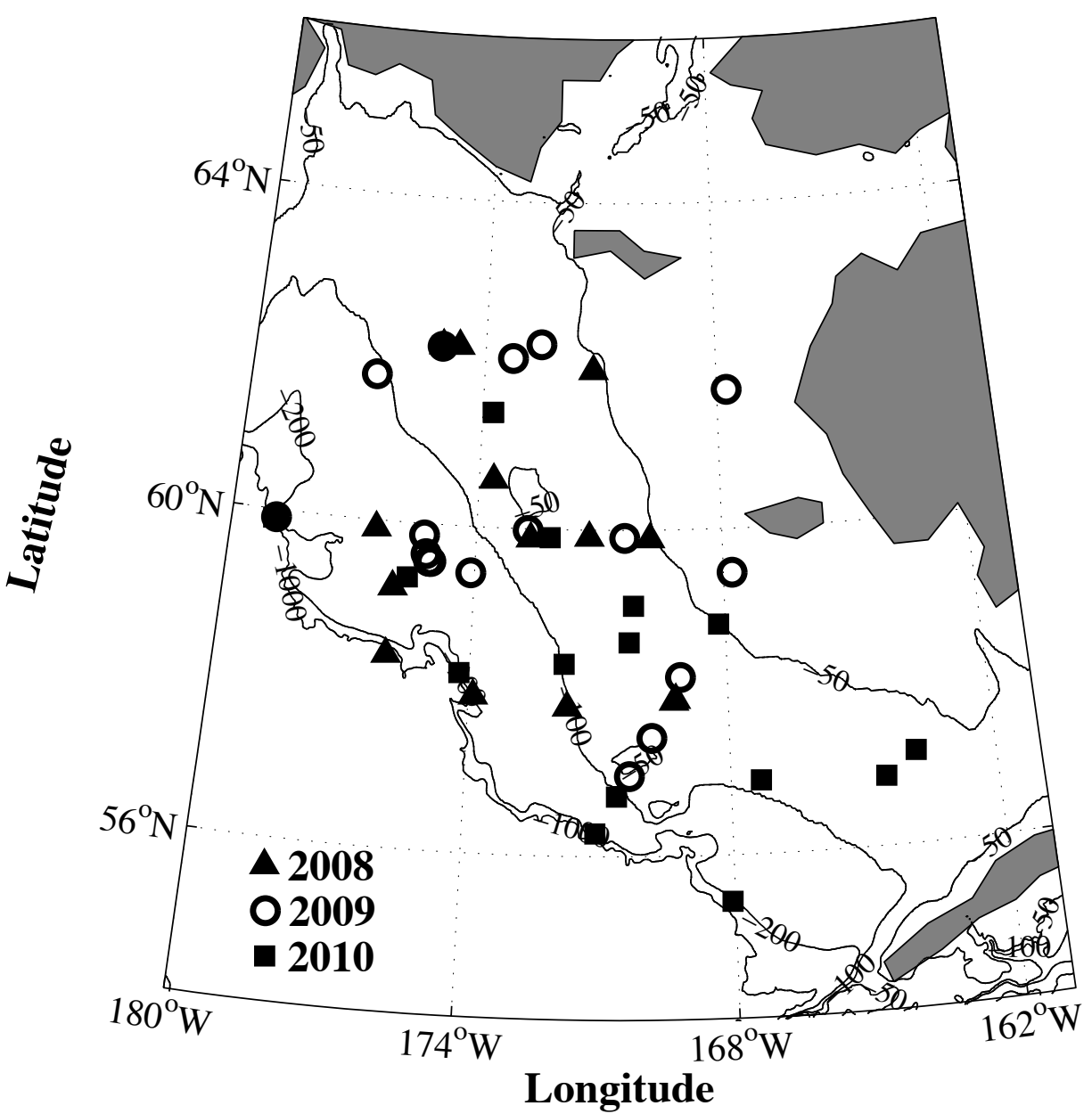

1227 
1227 Figure 2.

1228

1229

1230

1231
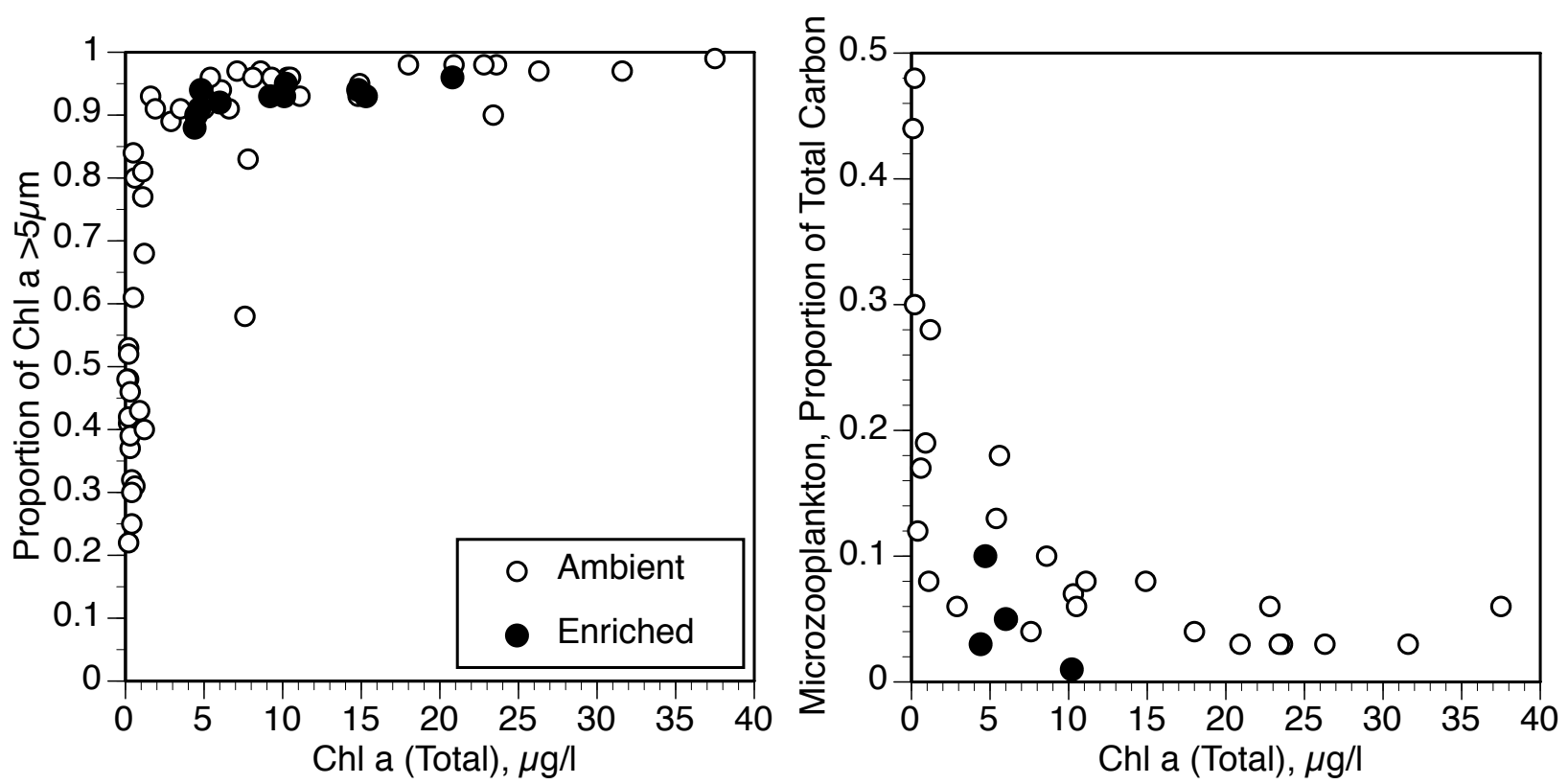

1232 
1232 Figure 3.

1233

1234

1235
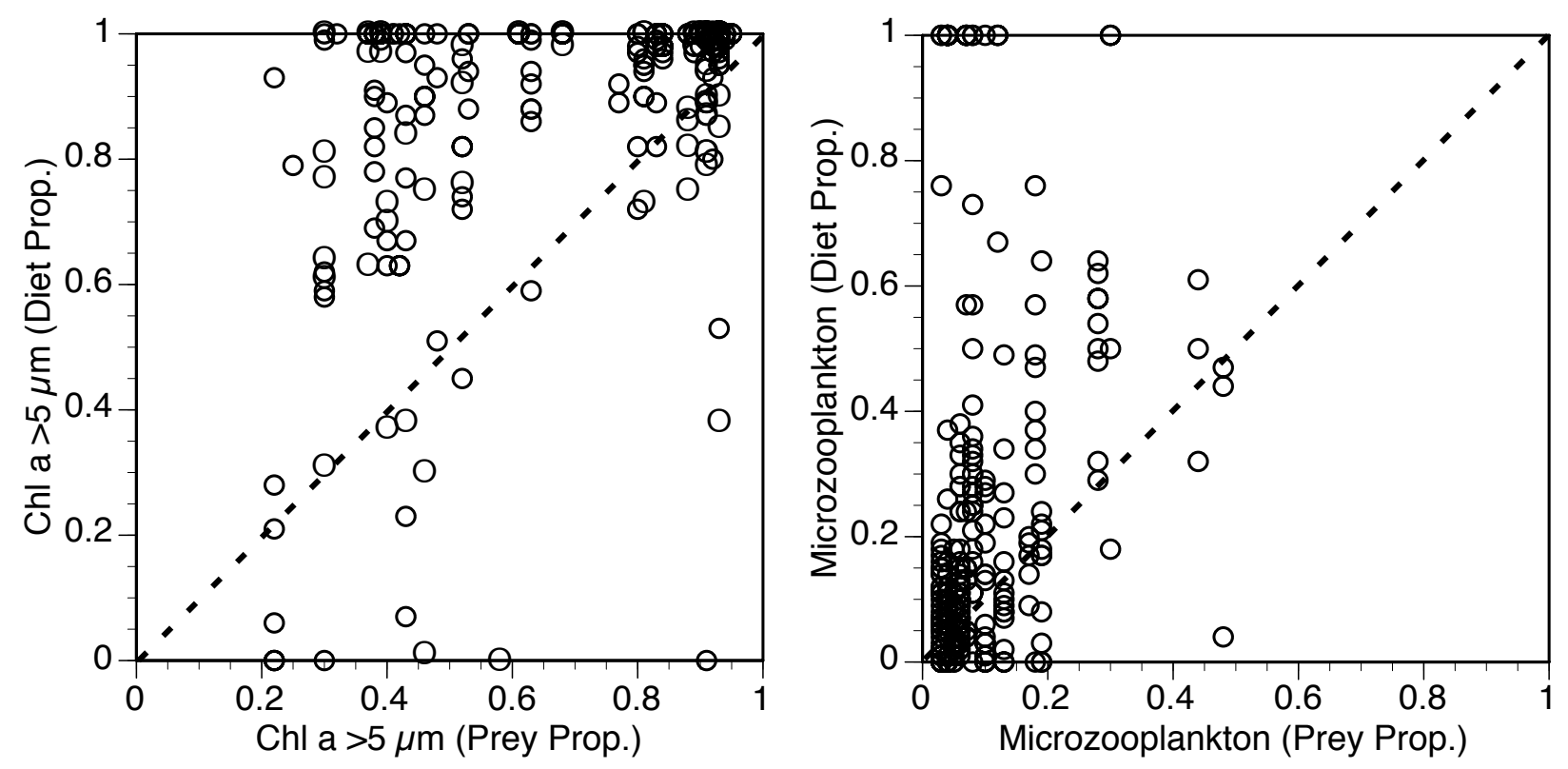

1236 
1236

1237

1238

1239

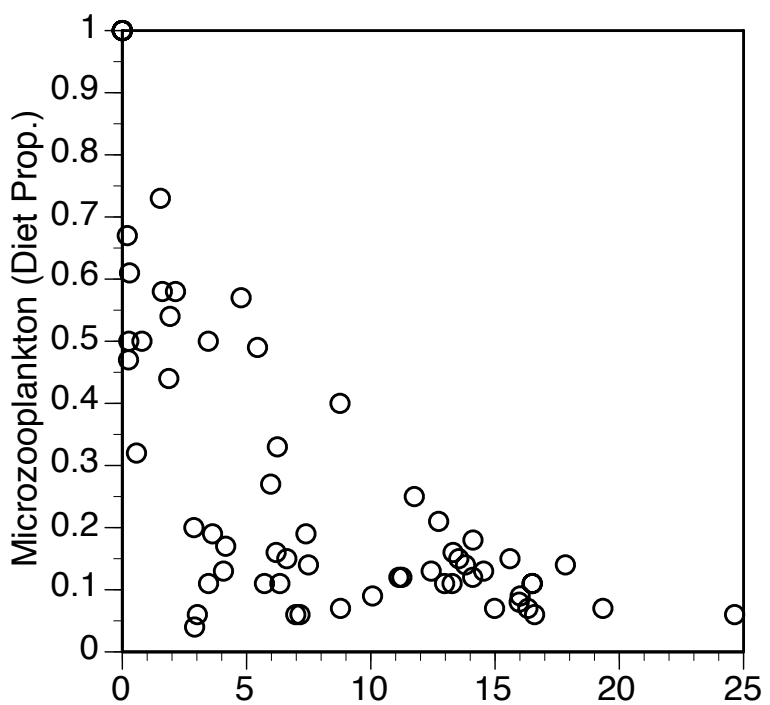

1240

Figure 4.

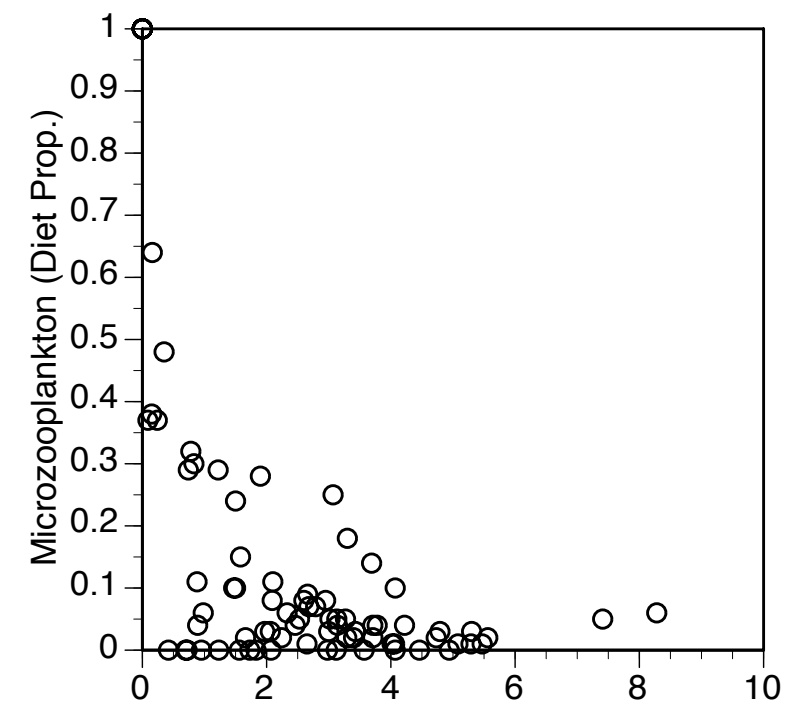

Chlorophyll Ingestion Rate, \% Body Carbon Day ${ }^{-1}$ Chlorophyll Ingestion Rate, \% Body Carbon Day ${ }^{-1}$ 
1241 Figure 5.

1242

1243

1244

1245

1246

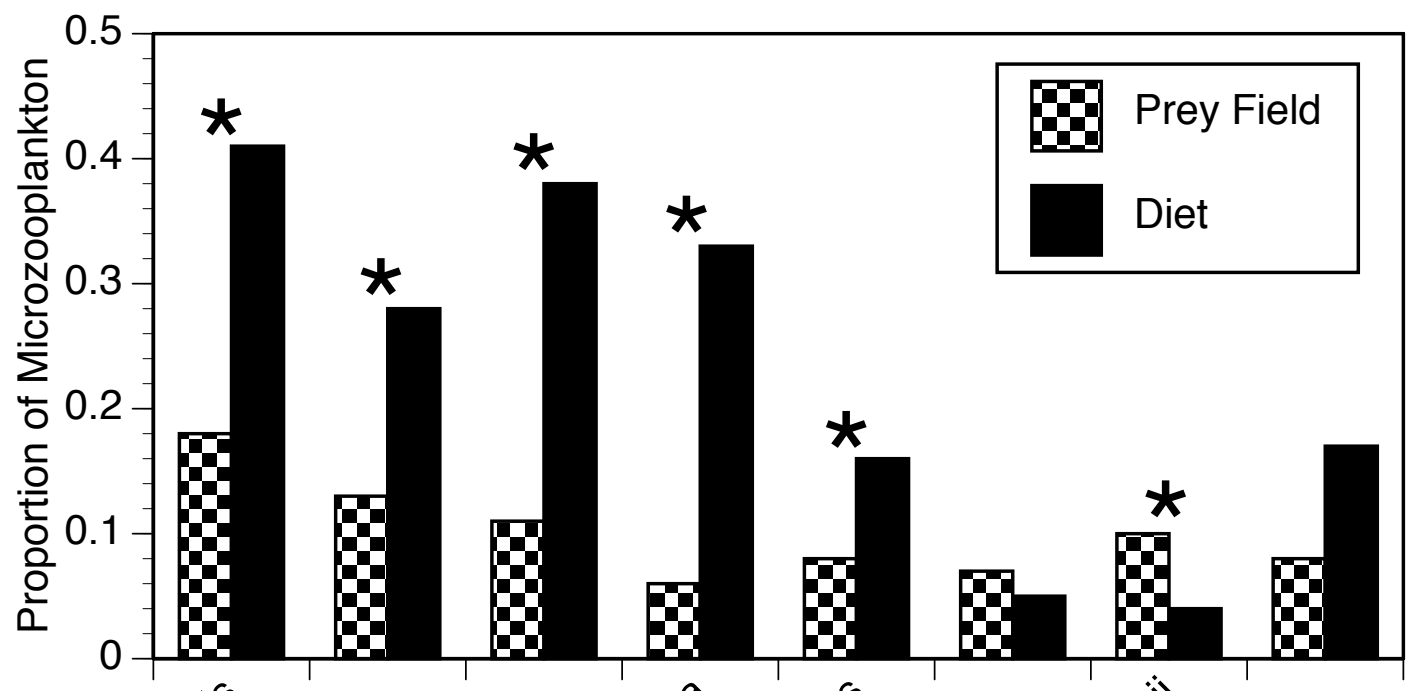

1247

1248

1249

1250

1251

1252

1253

1254

1255

1256

1257

1258

1259

1260

1261

1262

1263

1264

1265

1266

1267 
1268 Figure 6.

1269

1270

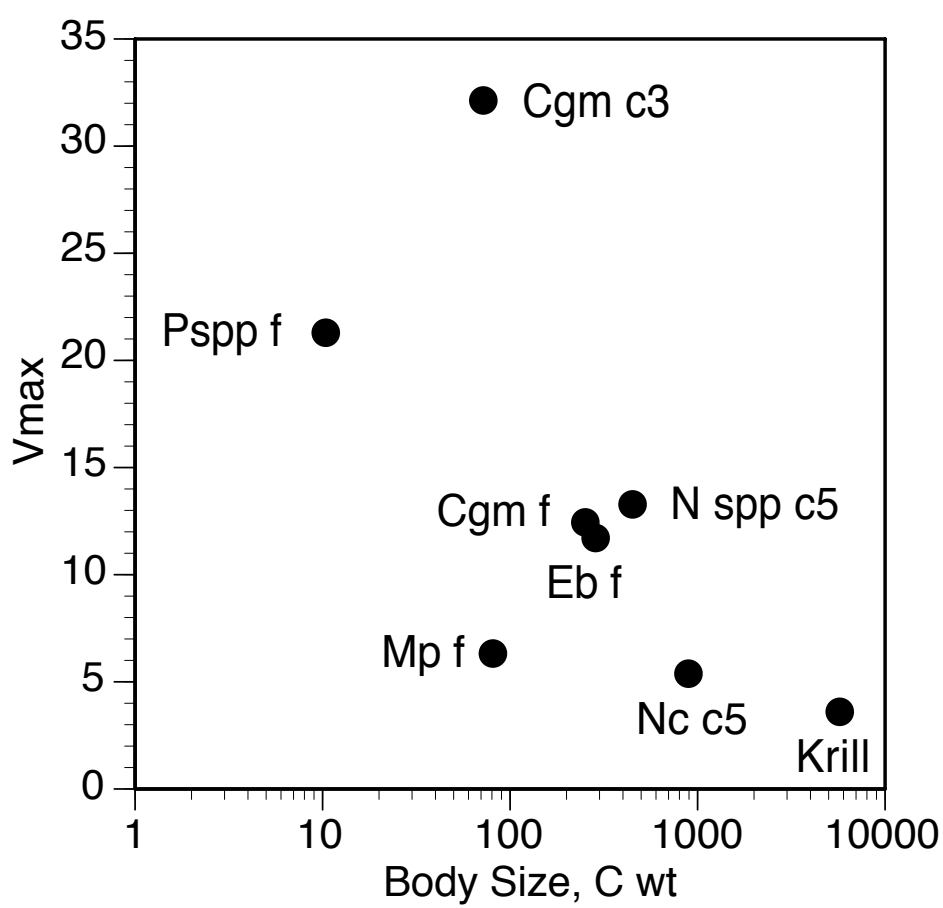

1271 
1272 Figure 7.

1273

1274
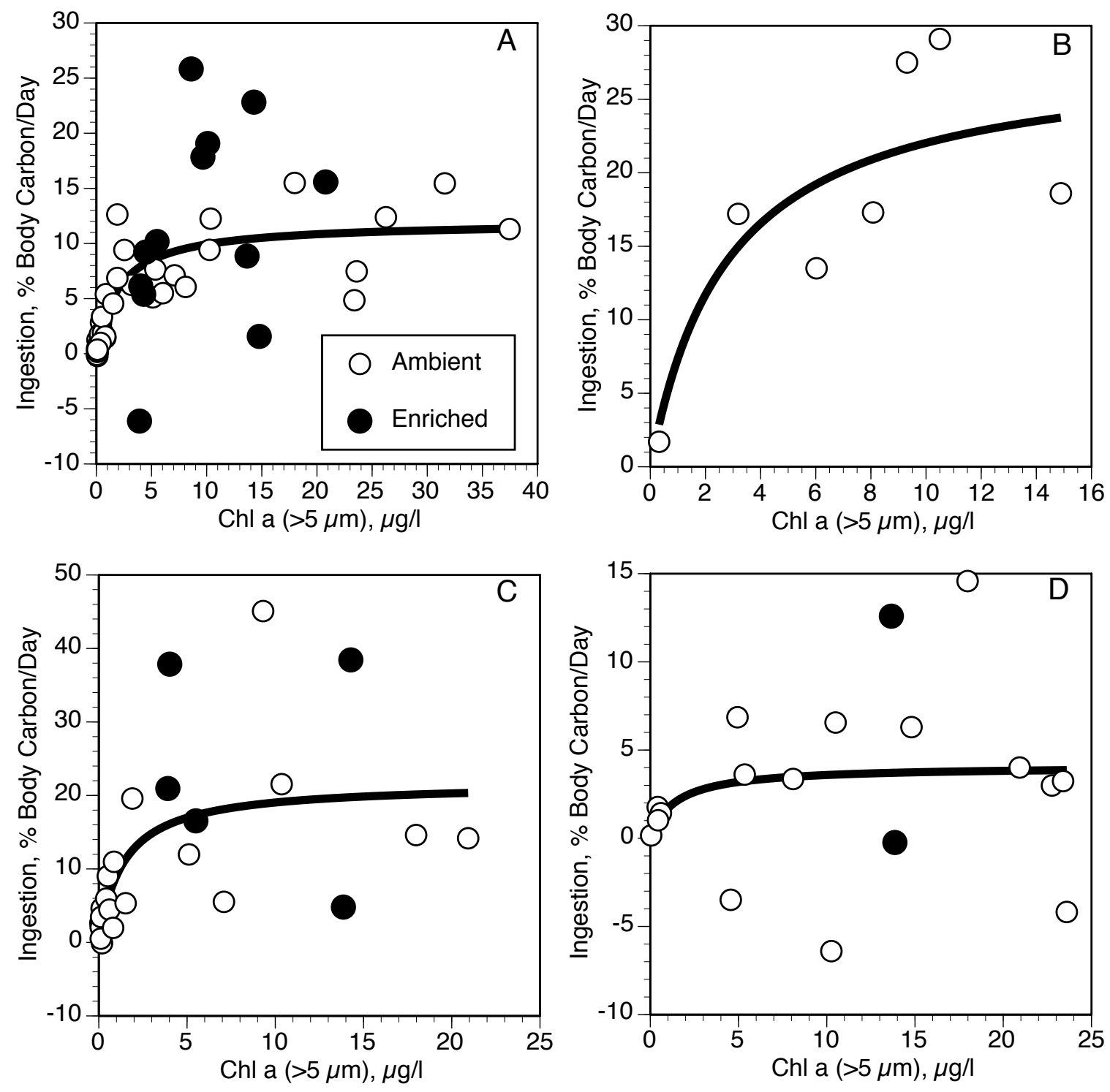

1275

1276 
1276 Figure 7 continued.

1277

1278
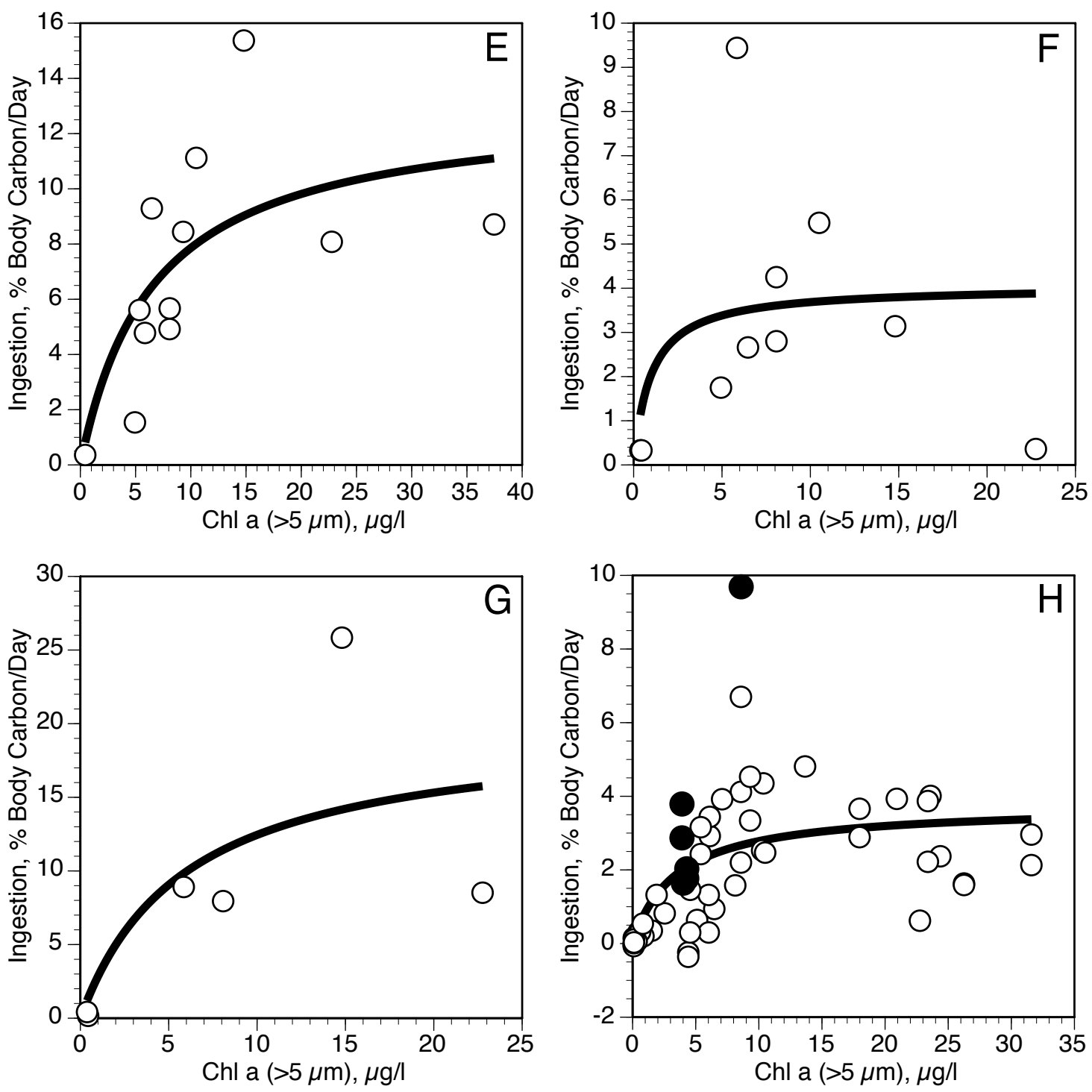

1279

1280 

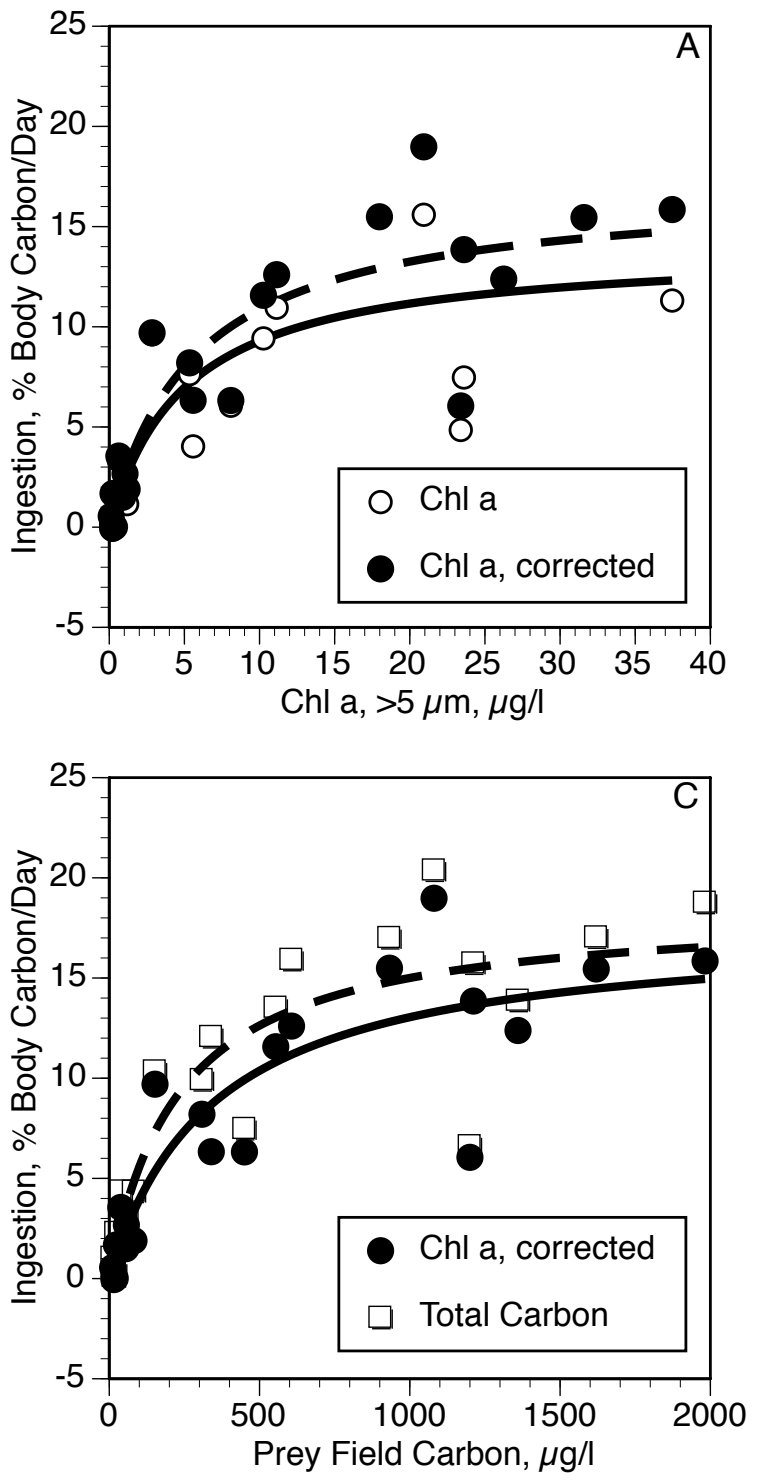

1280

1281

1282

1283

Figure 8.

1285
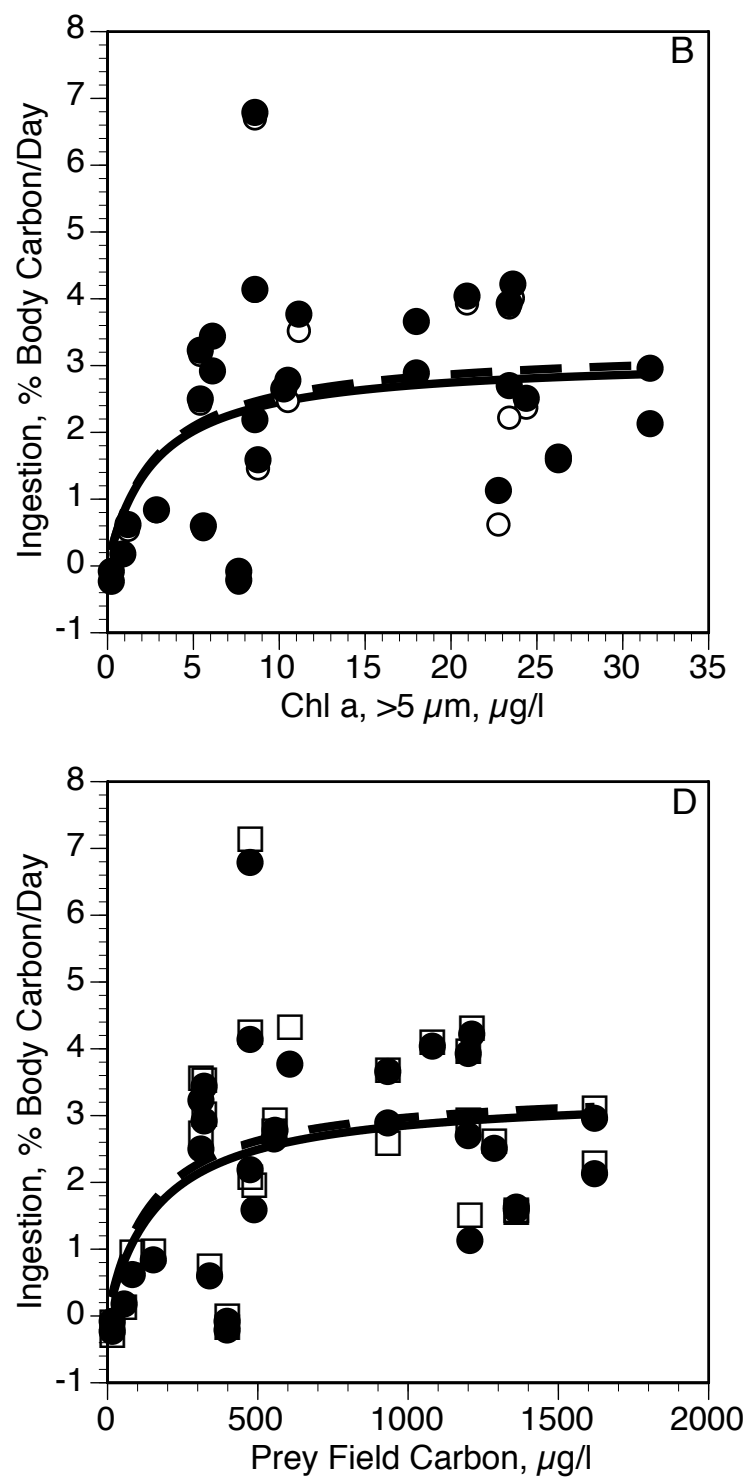
1285

1286

1287

1288

1289
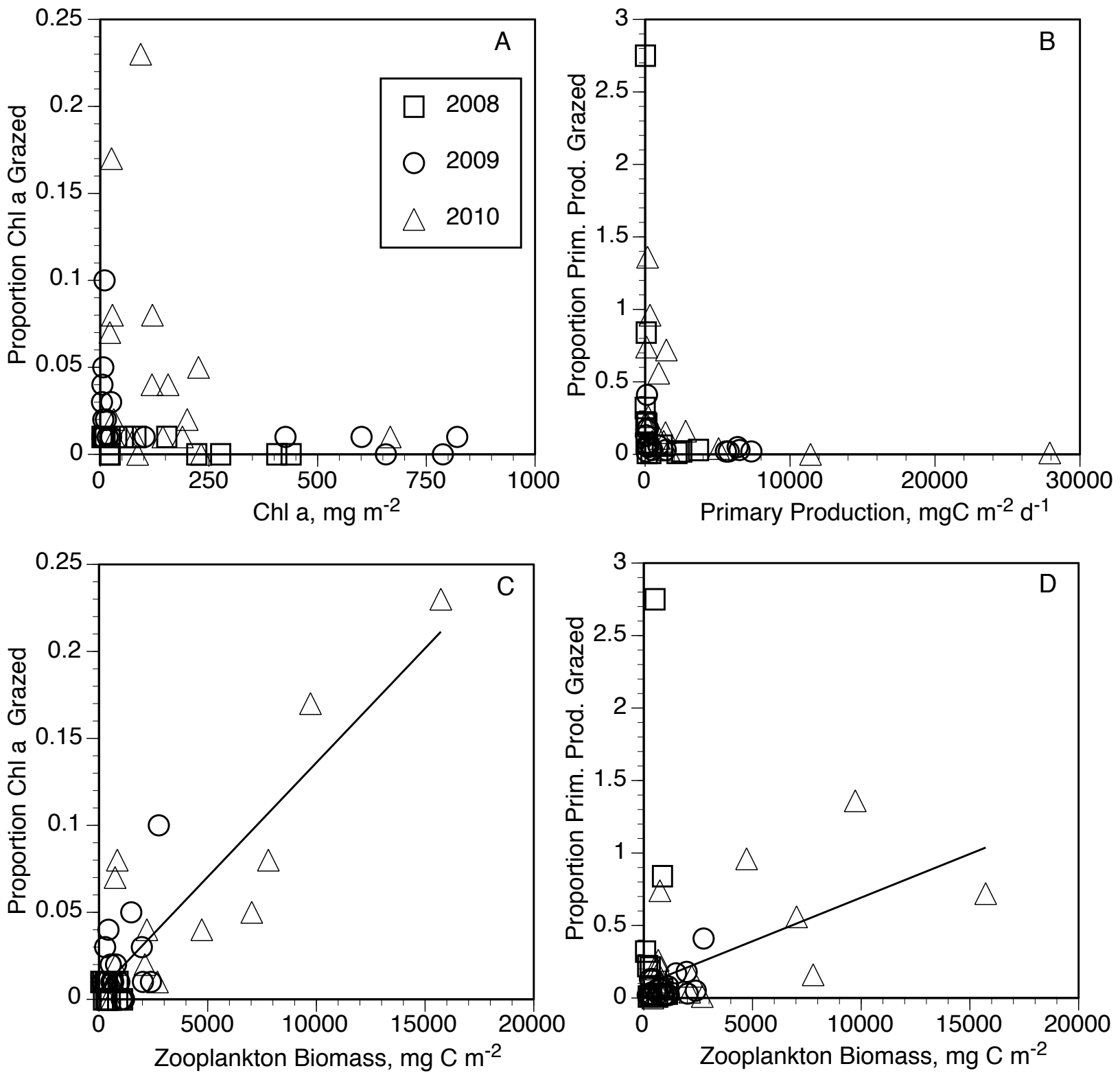

Figure 9.

1290

1291

1292

1293

1294

1295

1296

1297

1298

1299 
1300 Table 1. Environmental conditions and prey field concentrations. The mean ( \pm sd)

1301 experimental conditions during each cruise are shown, including incubation temperature, 1302 chlorophyll concentration, proportion of chlorophyll $>5 \mu \mathrm{m}$, and the carbon biomass of 1303 chlorophyll $a$ and microzooplankton in the experimental water.

1304

\begin{tabular}{cccccccc} 
Cruise & Dates & $\begin{array}{c}\text { Exps. } \\
\mathrm{n}\end{array}$ & $\begin{array}{c}\mathrm{Temp} \\
{ }^{\circ} \mathrm{C}\end{array}$ & $\begin{array}{c}\mathrm{Chl} a \\
\mu \mathrm{g} \mathrm{Chl} a \mathrm{l}^{-1}\end{array}$ & $\begin{array}{c}\mathrm{Chl} a,>5 \\
\text { Proportion }\end{array}$ & $\begin{array}{c}\text { Chl } a \\
\text { Biomass } \\
\mu \mathrm{g} \mathrm{C}^{-1}\end{array}$ & $\begin{array}{c}\mu z p \\
\text { Biomass } \\
\mu \mathrm{g} \mathrm{C}^{-1}\end{array}$ \\
\hline HLY0802 & $4 / 2 / 08-5 / 1 / 08$ & 14 & $-1.2 \pm 0.9$ & $4.6 \pm 5.8$ & $0.76 \pm 0.23$ & $230 \pm 290$ & $18.6 \pm 16.6$ \\
HLY0902 & $4 / 6 / 09-5 / 8 / 09$ & 18 & $-0.9 \pm 0.5$ & $7.0 \pm 11.4$ & $0.64 \pm 0.30$ & $350 \pm 570$ & $33.7 \pm 33.6$ \\
TN249 & $5 / 12 / 10-6 / 11 / 10$ & 18 & $1.9 \pm 1.1$ & $9.9 \pm 8.8$ & $0.82 \pm 0.21$ & $495 \pm 440$ & $45.0 \pm 19.0$
\end{tabular}


Table 2. Prey field vs. diet comparisons. The proportion of microzooplankton biomass (carbon) in the prey field and diet (mean \pm sd values shown) are compared for each taxon with the significance level based on the non-parametric Wilcoxon Matched-Pairs Signed Ranks Test (p). The electivity indices (D) within each taxon, positive values indicating preference for microzooplankton and negative values a preference for chlorophyll, are compared using the nonparametric Wilcoxon Signed Ranks Test (p). Electivity index (D) comparisons between taxa were significant $(\mathrm{p}<0.0001)$ based on the non-parametric Kruskal-Wallis One-Way ANOVA. Dunn's Multiple Comparisons test was used in post-hoc comparisons with letters $(a, b)$ indicating groupings $(\mathrm{p}<0.05)$. The sample size for Acartia was too small to perform the test. Chlorophyll ingestion rates used in the diet proportion estimates were corrected for trophic

1317 cascades (see Methods for details).

\section{Microzooplankton Preferences Microzooplankton Proportion \\ n Prey Field \\ Diet \\ p Electivity Index \\ D p}

Mid Shelf copepods Acartia longiremis Calanus spp. 3

$\begin{array}{cc}0.18 & 0.41 \pm 0.05 \\ 0.13 \pm 0.13 & 0.28 \pm 0.26\end{array}$
$<0.0001$ $0.52 \pm 0.07$

Pseudocalanus spp.

$0.11 \pm 0.08$

$0.38 \pm 0.28<0.0001$

$0.39 \pm 0.36^{\mathrm{a}}$

$0.53 \pm 0.46^{\mathrm{a}}$

$<0.0001$

Outer shelf/slope copepods

$\begin{array}{lcccccc}\text { Eucalanus bungii } & 9 & 0.10 \pm .07 & 0.04 \pm 0.05 & 0.0078 & -0.52 \pm 0.39^{\mathrm{b}} & 0.0177 \\ \text { Metridia pacifica } & 32 & 0.06 \pm 0.03 & 0.33 \pm 0.31 & <0.0001 & 0.58 \pm 0.37^{\mathrm{a}} & <0.0001 \\ \text { Neocalanus cristatus } & 15 & 0.08 \pm 0.06 & 0.16 \pm 0.09 & 0.0009 & 0.32 \pm 0.37^{\mathrm{a}, \mathrm{b}} & 0.0043 \\ \text { Neocalanus spp. } & 21 & 0.07 \pm 0.03 & 0.05 \pm 0.05 & \mathrm{~ns} & -0.20 \pm 0.54^{\mathrm{b}} & \mathrm{ns} \\ & & & & & & \\ \text { Euphausiids } & & & & & & \\ \text { Thysanoessa } \text { spp. } & 87 & 0.08 \pm 0.08 & 0.17 \pm 0.29 & \text { ns } & -0.14 \pm 0.64^{\mathrm{b}} & 0.004\end{array}$


1321 Table 3. Clearance of microzooplankton by size and type. The comparisons between clearance 1322 rates for large and small microzooplankton and for ciliates and dinoflagellates are shown for 1323 each taxon. The level of significance (p) is shown for the non-parametric Matched-Pairs Signed 1324 Ranks Test for each comparison. The sample size for Acartia was too small to perform the test.

\begin{tabular}{|c|c|c|c|c|c|c|c|}
\hline & \multicolumn{7}{|c|}{ Clearance of microzooplankton, $\mathrm{ml}_{\mu \mathrm{gC}} \mathrm{day}^{-1}$} \\
\hline & \multirow[b]{2}{*}{$\mathbf{n}$} & \multicolumn{3}{|c|}{ Size } & \multicolumn{3}{|c|}{ Type } \\
\hline & & $<40 \mu \mathrm{m}$ & $>40 \mu \mathrm{m}$ & p & Ciliate & Dinoflagellate & $\mathbf{p}$ \\
\hline \multicolumn{8}{|l|}{ Mid shelf copepods } \\
\hline Acartia longiremis & 3 & $0.90 \pm 1.11$ & $2.19 \pm 0.36$ & & $7.39 \pm 2.79$ & $1.27 \pm 0.29$ & \\
\hline Calanus spp. & 74 & $0.31 \pm 0.75$ & $1.57 \pm 1.44$ & $<0.0001$ & $0.92 \pm 0.94$ & $1.04 \pm 0.94$ & ns \\
\hline Pseudocalanus spp. & 23 & $1.54 \pm 1.29$ & $2.51 \pm 2.35$ & ns & $1.96 \pm 2.84$ & $2.24 \pm 1.11$ & ns \\
\hline \multicolumn{8}{|l|}{$\begin{array}{l}\text { Outer shelf/slope } \\
\text { copepods }\end{array}$} \\
\hline Eucalanus bungii & 9 & $-0.02 \pm 0.15$ & $0.20 \pm 0.30$ & ns & $-0.02 \pm 0.15$ & $0.07 \pm 0.15$ & ns \\
\hline Metridia pacifica & 32 & $0.34 \pm 0.3$ & $1.14 \pm 0.77$ & $<0.0001$ & $1.01 \pm 0.51$ & $0.67 \pm 0.54$ & 0.0008 \\
\hline Neocalanus cristatus & 15 & $0.06 \pm 0.17$ & $0.18 \pm 0.29$ & 0.0181 & $0.11 \pm 0.22$ & $0.12 \pm 0.19$ & ns \\
\hline Neocalanus spp. & 21 & $0.09 \pm 0.14$ & $0.24 \pm 0.19$ & 0.037 & $0.14 \pm 0.16$ & $0.17 \pm 0.20$ & ns \\
\hline \multicolumn{8}{|l|}{ Euphausiids } \\
\hline Thysanoessa spp. & 87 & $0.05 \pm 0.09$ & $0.08 \pm 0.17$ & 0.0058 & $0.12 \pm 0.19$ & $0.03 \pm 0.08$ & $<0.0001$ \\
\hline
\end{tabular}


Table 4. Michaelis-Menten relationships. Parameter estimates for relationships for ingestion rate as a function of initial chlorophyll $a$ concentration (total and $>5 \mu \mathrm{m}$ ) are given. Parameter estimates for Vmax and $\mathrm{Km}$, and $\mathrm{R}^{2}$ values are provided for uncorrected rates and temperature corrected rates set to $0^{\circ} \mathrm{C}$, assuming a $\mathrm{Q}_{10}$ coefficient of 2 , for both nitrogen- and carbon-specific ingestion rates for each taxon grouping. In addition, the stages included in the grouping, their mean $( \pm \mathrm{sd})$ weight $(\mathrm{N}$ and $\mathrm{C}), \mathrm{C}: \mathrm{N}$ ratio, and the total number of experiments and samples included in the relationship are given. Ingestion rates were not corrected for trophic cascades.

\begin{tabular}{|c|c|c|c|c|c|c|c|c|c|c|c|c|c|c|}
\hline \multirow[t]{2}{*}{ Taxon } & \multirow[t]{2}{*}{ Stages } & \multirow[t]{2}{*}{ N wt $(\mu g)$} & \multirow[t]{2}{*}{ C wt $(\mu \mathrm{g})$} & \multirow[t]{2}{*}{$\mathrm{C}: \mathrm{N}$} & \multirow{2}{*}{$\begin{array}{c}\text { Exp. } \\
\mathrm{n}\end{array}$} & \multirow{2}{*}{$\begin{array}{c}\text { Sample } \\
\mathrm{n} \\
\end{array}$} & \multirow{2}{*}{$\begin{array}{c}\text { Chl } a \\
\text { fraction }\end{array}$} & \multirow{2}{*}{$\begin{array}{c}\text { Temp. } \\
\text { corr. } \\
\text { to } 0^{\circ} \mathrm{C}\end{array}$} & \multicolumn{3}{|c|}{$\begin{array}{c}\text { Nitrogen }(\% \text { Body } \\
\text { wt/day vs. Chl } a, \\
\mu \mathrm{g} / \mathrm{l})\end{array}$} & \multicolumn{3}{|c|}{$\begin{array}{c}\text { Carbon (\% Body } \\
\text { wt/day vs. Chl } a, \\
\mu \mathrm{g} / \mathrm{l})\end{array}$} \\
\hline & & & & & & & & & $V_{\max }$ & $\mathbf{K}_{\mathbf{m}}$ & $\mathbf{R}^{2}$ & $\mathbf{V}_{\max }$ & $\mathbf{K}_{\mathrm{m}}$ & $\mathbf{R}^{2}$ \\
\hline \multirow[t]{4}{*}{ Calanus spp. } & C5-Adult & $60 \pm 14$ & $252 \pm 65$ & 4.20 & 42 & 128 & Total & None & 6.47 & 2.89 & 0.67 & 12.44 & 3.09 & 0.70 \\
\hline & & & & & & & Total & $\mathrm{Q} 10=2$ & 6.08 & 2.30 & 0.66 & 11.79 & 2.53 & 0.69 \\
\hline & & & & & & & $>5 \mu \mathrm{m}$ & None & 6.23 & 1.89 & 0.72 & 11.95 & 2.05 & 0.75 \\
\hline & & & & & & & $>5 \mu \mathrm{m}$ & $\mathrm{Q} 10=2$ & 5.92 & 1.53 & 0.73 & 11.43 & 1.68 & 0.75 \\
\hline \multirow[t]{4}{*}{ Calanus spp. } & $\mathrm{C} 1-\mathrm{C} 4$ & $10 \pm 7$ & $72 \pm 61$ & 7.20 & 7 & 21 & Total & None & 23.30 & 3.41 & 0.50 & 32.13 & 5.20 & 0.58 \\
\hline & & & & & & & Total & $\mathrm{Q} 10=2$ & 21.44 & 3.39 & 0.46 & 28.41 & 4.77 & 0.57 \\
\hline & & & & & & & $>5 \mu \mathrm{m}$ & None & 22.28 & 2.12 & 0.58 & 28.28 & 2.84 & 0.68 \\
\hline & & & & & & & $>5 \mu \mathrm{m}$ & $\mathrm{Q} 10=2$ & 20.67 & 2.21 & 0.54 & 25.70 & 2.81 & 0.68 \\
\hline \multirow[t]{4}{*}{ Pseudocalanus spp. } & $\begin{array}{l}\text { Adult } \\
\text { Female }\end{array}$ & $2.4 \pm 0.6$ & $10.4 \pm 3.7$ & 4.33 & 23 & 69 & Total & None & 12.40 & 1.89 & 0.37 & 21.29 & 1.89 & 0.41 \\
\hline & & & & & & & Total & $\mathrm{Q} 10=2$ & 11.81 & 1.57 & 0.36 & 20.26 & 1.57 & 0.40 \\
\hline & & & & & & & $>5 \mu \mathrm{m}$ & None & 12.64 & 1.40 & 0.43 & 21.68 & 1.39 & 0.48 \\
\hline & & & & & & & $>5 \mu \mathrm{m}$ & $\mathrm{Q} 10=2$ & 12.12 & 1.19 & 0.42 & 20.77 & 1.18 & 0.47 \\
\hline \multirow[t]{2}{*}{ Metridia pacifica } & $\begin{array}{l}\text { Adult } \\
\text { Female }\end{array}$ & $20 \pm 4$ & $81 \pm 17$ & 4.05 & 18 & 54 & Total & None & 3.24 & 7.59 & 0.10 & 6.32 & 7.37 & 0.10 \\
\hline & & & & & & & Total & $\mathrm{Q} 10=2$ & 3.42 & 5.19 & 0.21 & 6.68 & 4.97 & 0.21 \\
\hline
\end{tabular}




\begin{tabular}{|c|c|c|c|c|c|c|c|c|c|c|c|c|c|c|}
\hline & & & & & & & $>5 \mu \mathrm{m}$ & None & 2.73 & 4.08 & 0.07 & 5.29 & 3.84 & 0.07 \\
\hline & & & & & & & $>5 \mu \mathrm{m}$ & $\mathrm{Q} 10=2$ & 3.02 & 2.81 & 0.17 & 5.91 & 2.71 & 0.18 \\
\hline \multirow[t]{4}{*}{ Eucalanus bungii } & C5,Female & $71 \pm 20$ & $286 \pm 89$ & 4.03 & 6 & 18 & Total & None & 7.08 & 7.63 & 0.95 & 11.71 & 4.67 & 0.85 \\
\hline & & & & & & & Total & $\mathrm{Q} 10=2$ & 6.31 & 5.60 & 0.91 & 11.12 & 3.92 & 0.79 \\
\hline & & & & & & & $>5 \mu \mathrm{m}$ & None & 6.37 & 5.00 & 0.99 & 10.53 & 2.63 & 0.94 \\
\hline & & & & & & & $>5 \mu \mathrm{m}$ & $\mathrm{Q} 10=2$ & 5.64 & 3.39 & 0.98 & 10.17 & 2.15 & 0.89 \\
\hline \multirow[t]{4}{*}{ Neocalanus cristatus } & $\mathrm{C} 5$ & $172 \pm 60$ & $894 \pm 484$ & 5.20 & 6 & 14 & Total & None & 2.17 & 4.58 & 0.72 & 5.38 & 9.60 & 0.95 \\
\hline & & & & & & & Total & $\mathrm{Q} 10=2$ & 1.71 & 3.71 & 0.63 & 3.97 & 7.08 & 0.84 \\
\hline & & & & & & & $>5 \mu \mathrm{m}$ & None & 1.95 & 2.61 & 0.75 & 4.48 & 5.61 & 0.97 \\
\hline & & & & & & & $>5 \mu \mathrm{m}$ & $\mathrm{Q} 10=2$ & 1.64 & 2.55 & 0.70 & 3.59 & 4.66 & 0.89 \\
\hline \multirow{4}{*}{$\begin{array}{l}\text { Neocalanus spp. } \\
\text { (flemingeri/plumchrus) }\end{array}$} & $\mathrm{C} 4, \mathrm{C} 5$ & $50 \pm 22$ & $450 \pm 241$ & 9.00 & 12 & 36 & Total & None & 14.04 & 7.31 & 0.45 & 13.28 & 8.11 & 0.45 \\
\hline & & & & & & & Total & $\mathrm{Q} 10=2$ & 12.64 & 6.96 & 0.51 & 12.00 & 7.76 & 0.52 \\
\hline & & & & & & & $>5 \mu \mathrm{m}$ & None & 13.81 & 5.86 & 0.46 & 13.06 & 6.63 & 0.50 \\
\hline & & & & & & & $>5 \mu \mathrm{m}$ & $\mathrm{Q} 10=2$ & 12.55 & 5.77 & 0.58 & 11.91 & 6.54 & 0.62 \\
\hline \multirow[t]{4}{*}{ Thysanoessa raschii } & Juv/Adult & $1301 \pm 1010$ & $5719 \pm 4833$ & 4.40 & 44 & 128 & Total & None & 2.30 & 6.05 & 0.62 & 3.94 & 4.77 & 0.54 \\
\hline & & & & & & & Total & $\mathrm{Q} 10=2$ & 2.20 & 5.31 & 0.56 & 3.87 & 4.29 & 0.48 \\
\hline & & & & & & & $>5 \mu \mathrm{m}$ & None & 2.25 & 5.06 & 0.64 & 3.88 & 4.04 & 0.57 \\
\hline & & & & & & & $>5 \mu \mathrm{m}$ & $\mathrm{Q} 10=2$ & 2.17 & 4.51 & 0.58 & 3.82 & 3.67 & 0.51 \\
\hline Euphausiid (All) & Juv/Adult & $1269 \pm 979$ & $5731 \pm 4775$ & 4.52 & 55 & 159 & Total & None & 2.16 & 6.50 & 0.52 & 3.60 & 4.83 & 0.46 \\
\hline T. raschii, T. inermis, & & & & & & & Total & $\mathrm{Q} 10=2$ & 2.03 & 5.40 & 0.47 & 3.52 & 4.21 & 0.40 \\
\hline
\end{tabular}


$\begin{array}{llllllll}>5 \mu \mathrm{m} & \text { None } & 2.18 & 5.83 & 0.57 & 3.67 & 4.43 & 0.51\end{array}$

$>5 \mu \mathrm{m} \quad$ Q10=2 $\quad 2.06 \quad 4.81 \quad 0.53 \quad 3.59 \quad 3.84 \quad 0.46$ 
1334 Table 5. Ingestion measurement comparisons. The mean $( \pm \mathrm{sd})$ values for ingestion of 1335 chlorophyll $a$, corrected chlorophyll $a$ (Nejstgaard et al. (2001) correction for trophic cascades in 1336 experimental jars applied), and total carbon (corrected chlorophyll a and microzooplankton) for the subset of experiments where chlorophyll $a$ and microzooplankton ingestion rates were determined are shown for each taxon. In addition, mean values are given for the proportional increase in ingestion rate for the corrected chlorophyll $a$ relative to uncorrected chlorophyll $a$, and total carbon relative to corrected chlorophyll $a$. Data are not temperature corrected.

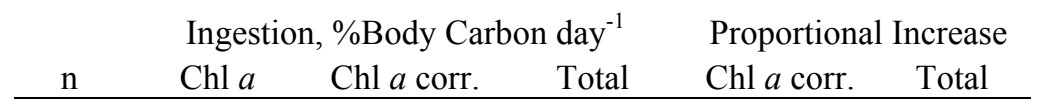

Mid shelf copepods

Acartia longiremis

Calanus spp.

$3 \quad 11.5 \pm 3.0$

$15.3 \pm 3.2 \quad 25.9 \pm 4.4$

0.33

0.69

Pseudocalanus spp.

$\begin{array}{ll}74 & 7.7 \pm 7.7\end{array}$

$9.7 \pm 10.3 \quad 11.8 \pm 11.8$

0.26

0.21

$\begin{array}{ll}23 & 9.9 \pm 9.2\end{array}$

$14.2 \pm 11.8 \quad 20.0 \pm 13.0$

0.44

0.41

Outer shelf/slope copepods

Eucalanus bungii

Metridia pacifica

Neocalanus cristatus

Neocalanus spp.

$\begin{array}{cc}9 & 6.0 \pm 4.3 \\ 32 & 4.2 \pm 4.4 \\ 15 & 3.5 \pm 5.0 \\ 21 & 6.5 \pm 3.3\end{array}$

$6.1 \pm 4.5$

$$
6.3 \pm 4.6
$$

0.03

0.03

$6.0 \pm 4.7$

$7.5 \pm 4.8$

0.41

0.26

$4.1 \pm 5.1 \quad 4.5 \pm 5.2$

0.15

0.10

$7.2 \pm 3.9$

$7.5 \pm 4.2$

0.10

0.06

Euphausiids

1342

Thysanoessa spp.

\section{8}

$2.2 \pm 1.8$

$2.3 \pm 1.8$

$2.5 \pm 1.9$

0.04

0.07

1343 
44 Table 6. Grazing Impacts by cruise, region $\left(<\right.$ or $\left.>59.8^{\circ} \mathrm{N}\right)$, domain $(<$ or $>100 \mathrm{~m})$, and bloom 45 conditions (primary production $<$ or $\left.>1 \mathrm{gC} \mathrm{m}^{-2} \mathrm{~d}^{-1}\right)$. Mean values $( \pm \mathrm{sd}$ ) are provided for

46 integrated mesozooplankton biomass, integrated chlorophyll $a$, integrated primary production,

47 integrated mesozooplankton grazing rates, and the proportions of the chlorophyll $a$ standing

48 stock and primary production that were grazed each day. Statistical comparisons were made to

49 test for differences in the proportion of primary production grazed within each grouping. The

50 non-parametric Kruskal-Wallis one-way ANOVA was used to test for differences between

51 cruises and the non-parametric Mann-Whitney test for the remaining paired comparisons. Only

52 the proportion of primary production grazed between non-bloom and bloom conditions was

53 significantly different $(* \mathrm{p}=0.0006)$. Grazing impact estimates not corrected for trophic

54 cascades.

55

\begin{tabular}{|c|c|c|c|c|c|}
\hline Zoop. & Int. & Int. & Zoop. & Proportion & Proportion \\
\hline $\mathrm{mgC} \mathrm{m} \mathrm{m}^{-2}$ & $\begin{array}{c}\text { Chl a } \\
\text { mgChla m- }\end{array}$ & $\begin{array}{l}\text { Prim. Prod. } \\
\mathrm{mgC} \mathrm{m}^{-2} \mathrm{~d}^{-1}\end{array}$ & $\begin{array}{c}\text { Graz. } \\
\operatorname{mgChl} a \mathrm{~m}^{-2} \mathrm{~d}^{-1}\end{array}$ & $\begin{array}{l}\text { Chl a } \\
\text { Grazed }\end{array}$ & $\begin{array}{l}\text { Prim. Prod. } \\
\text { Grazed }\end{array}$ \\
\hline
\end{tabular}

\section{Cruises}

2008

472

$\pm 307$

132

871

$\pm 1253$

0.64

0.01

0.38

$\pm 156$

$\pm 0.66$

$\pm 0.002$

$\pm 0.78$

2009

1075

220

2093

1.29

0.02

0.09

$\pm 759$

$\pm 317$

$\pm 2850$

$\pm 1.66$

$\pm 0.02$

$\pm 0.10$

2010

\section{8}

139

3319

4.31

0.05

0.34

$\pm 4259$

$\pm 149$

$\pm 6922$

$\pm 5.19$

$\pm 0.06$

$\pm 0.39$

\section{Region}

South

1817

$\pm 2461$

221

2585

$\pm 3047$

2.54

0.03

0.34

$\pm 2.74$

$\pm 0.04$

$\pm 0.62$

North

1549

81

1802

1.81

0.03

0.16

$\pm 3338$

$\pm 155$

$\pm 6028$

$\pm 4.62$

$\pm 0.05$

$\pm 0.17$

\section{Domain}

Inner/Middle

$631-70$

$\pm 569$

70

1050

$\pm 2248$

0.79

$\pm 0.93$

0.02

0.14

Outer

3393

304

3901

4.49

$\pm 0.03$

$\pm 0.16$

$\pm 4008$

$\pm 279$

$\pm 6387$

$\pm 5.01$

0.04

0.42

$\pm 0.0$

$\pm 0.69$

Bloom Conditions

Non Bloom

$$
\begin{array}{r}
1385 \\
\pm 2223
\end{array}
$$

75

$\pm 110$

247

$\pm 275$

1.28

$\pm 2.29$

0.03

0.37

Bloom

$$
2417
$$

317

$\pm 272$

5308

$\pm 6295$

4.03

$\pm 4.85$

$\pm 0.04$

$\pm 0.57$

$\pm 3730$

(27)

